
Early Health and School Outcomes for Children with Lesbian Parents:

Evidence from Sweden

\author{
Lina Aldén
}

Linnaeus University Centre for Discrimination and Integration Studies, Linnaeus University

Anders Björklund

Swedish Institute for Social Research, Stockholm University and IZA

Mats Hammarstedt

Linnaeus University Centre for Discrimination and Integration Studies, Linnaeus University 


\section{ABSTRACT \\ Early Health and School Outcomes for Children with Lesbian Parents: Evidence from Sweden ${ }^{1}$}

Sweden was early to legalize same-sex partnership (1995), to allow same-sex couples to adopt children (2003), and to offer same-sex couples fertility treatment through the national health system (2005). Using population data, we identify children of lesbian parents as those whose biological mother was a registered same-sex partner no later than six months after the child's birth. The number of such children increased markedly from 1995 to 2010 with a total of 750 children for the whole period. We find that boys and girls with lesbian parents had 2.4 percent lower birth weight than other children, a difference that is statistically significant from zero at the 5 percent level. Girls, but not boys, also have a higher probability of having a low birth weight. We follow these children until age ten and observe diseases of the respiratory system. Boys with lesbian parents have a significantly lower probability of such diseases $(-3.4$ percentage points), and girls with lesbian parents an insignificantly higher probability $(+2.4$ percentage points). Our analysis of school outcomes at age ten uses a small sample so precision is low. The point estimates show that boys with lesbian parents outperform other children by around 10 percentiles higher test scores in Math and Swedish. These differences are barely significant, while estimates for girls are lower and not significant. For all outcomes, we find that children with lesbian parents benefit from their mother's socio-economic status, whereas they suffer in terms of birth weight from having been exposed to fertility treatment.

JEL classification: I14, J12, J13

Keywords: lesbian parents, birth weight, early child outcomes

\section{Corresponding author:}

Anders Björklund

Swedish Institute for Social Research (SOFI)

Stockholm University

SE-10691 Stockholm

Sweden

Email: anders.bjorklund@sofi.su.se

\footnotetext{
${ }^{1}$ We are grateful to Markus Jäntti and to workshop and seminar participants at the Luxembourg Institute of Socio-Economic Research (LISER), Ratio, Swedish Institute for Social Research (SOFI), Universidad Carlos III de Madrid, University of Linz, University of Notre Dame and University of Uppsala for useful comments and discussions. Björklund acknowledges financial support from the Swedish Research Council for Health, Working Life and Welfare (FORTE).
} 


\section{Introduction}

The issue of same-sex marriages and the right for same-sex couples to adopt children is controversial and hotly debated in many countries. A major argument for opponents to such rights for same-sex couples is the concern that children who grow up in such families will suffer. A quite large number of studies have addressed the question how children with samesex parents fare in terms of health and school performance compared to other children. ${ }^{2}$ These studies have predominantly used US and Canadian data where the issue has been particularly controversial. Further, most studies have used small and unrepresentative samples.

In this paper, we explore the Swedish experience of same-sex marriages and right for samesex couples to adopt children. Sweden is an interesting case for at least two reasons. First, Sweden was early to legalize these rights to same-sex couples. A partnership act was introduced in 1995. In 2003, individuals in registered partnership received the same right to adopt children as married heterosexuals. Further, in 2005 homosexual women - in registered partnership or cohabiting - received the right to artificial insemination or in vitro fertilization (IVF-treatment) through the national health care system. Second, Swedish administrative register data offer the opportunity to compare the outcomes of children to homosexual parents with other children. By merging population registers with medical and school registers of the whole population, we can compare outcomes such as birth weight, health and scores on compulsory school tests at age ten between children with lesbian parents and all other children. We can also make the comparison with subsets of other children in ways that shed light on some possible mediating factors.

Why would we at all expect any substantial differences in important life outcomes such as physical or mental health, or school performance between children of same-sex parents and other children? This is hard to say. However, from the public discussion about these issues,

\footnotetext{
${ }^{2}$ Allen (2013) offers a recent survey.
} 
the previous literature and the actual circumstances facing same-sex couples, it is possible to hypothesize that some differences may occur.

One reason could be that the socio-economic status of same-sex parents differs from other parents. Differences in parental socio-economic status - be it income, education, occupation or a combination thereof - most likely represent a combination of genetic influence and nurturing resources. Thus, some differences between children of same-sex parents and other children will appear if their parents have different socio-economic status. A priori, there are no strong reasons to expect such differences in socio-economic background. They may very well depend on the country context. For Sweden, however, both Ahmed and Hammarstedt (2010) and Ahmed, Andersson and Hammarstedt (2011) report higher education among homosexual than heterosexual individuals, and this difference may also exist among homosexual and heterosexual parents.

Another reason for differences could be that homosexual couples have to rely on reproductive technologies that may have negative consequences. In particular, lesbian couples may rely on artificial fertility treatment (including IVF-treatment) more frequently than other parents. Our reading of the epidemiological literature, suggests that large negative effects of artificial fertility treatment are unlikely but that some effects cannot be ruled out. Wagenaar et al. (2008) offer a comprehensive survey.

Same-sex and opposite-sex parents may also differ in their parenting styles. Parenting has many dimensions. One is the timing of the birth of the child. A same-sex couple must plan their child bearing quite carefully so it is unlikely that their children are unwanted. In particular, there are no reasons to expect teenage births among same-sex couples, and children with teenage parents are generally associated with worse outcomes than other children. 
Another dimension of parenting is behavior during pregnancy. The rich literature about inutero effects and the Barker hypothesis suggests that behavior and nutrition during pregnancy may have a strong impact on the child. ${ }^{3}$ It is an open question whether there are differences between same-sex and opposite-sex parents in these respects.

But the most important aspect of parenting is probably the parenting style during childhood. Again, it is an open question whether one should expect any differences in this respect. It is, however, natural to address the question whether there are gender-specific effects of growing up with same-sex parents, e.g., if lesbian parents affect boys and girls differently.

It is also possible that homosexual parents and their children suffer from discrimination. This possibility is examined in the Spanish context by Diaz-Serrano and Meix-Llop (2016). In an internet field experiment, they find that schools were more hesitant to give feedback to gay parents during children's pre-registration period. Field experiments in the Swedish setting have also found clear evidence of discrimination against homosexual adults in both the labour and the housing market (Ahmed and Hammarstedt 2009, Ahmed, Andersson and Hammarstedt 2008 and 2013, and Hammarstedt, Ahmed and Andersson 2015).

Closely related to discrimination is stigmatization. If children of same-sex parents are treated badly by friends, or more generally in society, they may suffer in terms of health and school performance.

It is also possible that children with same-sex parents grow up in family structures that are different from those of other children in ways that generate different health and school outcomes. It seems likely that same-sex families are smaller than other families, and smaller family size is generally associated with better child outcomes than larger ones (e.g. Black, Devereux and Salvanes, 2005). Another possibility is that same-sex families are less stable

\footnotetext{
${ }^{3}$ Almond and Currie (2011) offer a useful survey of economists' contributions to this literature. Nilsson (forthcoming) reports convincing evidence about deleterious effects of alcohol consumption during pregnancy.
} 
than heterosexual ones and that therefore children in such families more frequently suffer from parental separations. ${ }^{4}$

We identify 750 children born from 1995 to 2010 with a biological mother who had entered registered partnership (or after 2009 marriage) with another women no later than six months after the birth of the child. We find that these children start out their lives with a circa 2.4 percent disadvantage in terms of birth weight. However, at age ten this initial negative difference had disappeared. In particular, boys with a lesbian biological mother had better health and school performance than boys with other parents.

The paper is organized as follows. Section 2 summarizes the previous, predominantly US, literature. We explain the Swedish institutional set-up in section 3. Section 4 presents our data. Section 5 reports our main empirical results. Section 6 contains some sensitivity analyses. We conclude in Section 7 with a summary and discussion of our results.

\section{Previous literature}

There is a growing literature on the issue of different types of outcomes for children raised by same-sex parents and on same-sex parenting. ${ }^{5}$ As regards outcomes for children with samesex parents, Allen (2013) presents more than fifty studies that focus on aspects such as psychological well-being, psychosocial adjustment and educational achievement. With few exceptions, most of the studies arrive at the same conclusion: There are no substantial differences for children of same-sex parents compared to children with opposite-sex parents.

However, studying psychological, psychosocial and educational outcomes among children raised by same-sex parents is, for different reasons, a challenge. Firstly, legalizing same-sex

\footnotetext{
${ }^{4}$ Andersson et al. (2006) and Kolk and Andersson (2016) show that same-sex families in general are more unstable than heterosexual ones, but it is an open question whether this also holds for families with children. See McLanahan, Tach and Schneider (2013) for a thorough discussion about the effects of parental separation on child outcomes.

${ }^{5}$ Surveys on the literature on different outcomes among children with same-sex parents and on same-sex parenting are found in Allen (2013), Marks (2012) and Tasker (2010).
} 
parenting is a relatively new phenomenon. Therefore, the number of children being raised by same-sex parents is small.

Secondly, limited access to reliable data from registers makes up an obstacle for different kinds of comparisons between children with same-sex parents and children with opposite-sex parents. Since same-sex parenting is a new phenomenon many children who are growing up in households with same-sex adults are children from previous heterosexual relationships. In most data sources it is not possible to distinguish between children being born and raised by two same-sex parents, and children who were born in an heterosexual relationship, but is living with one of his/her biological parents who currently is one part in a same-sex relationship. Besides this, it may also be that children are living in a household with two same-sex adults who are not in a sexual relationship. In most data sources it is not possible to distinguish between a child born and raised by two same-sex parents and a child raised by e.g. two sisters living together. As a result, it becomes impossible to distinguish the impact of the parents' sexual orientation on children's outcomes from the impact of, for example, divorce or parental death.

Another limitation in the data is due to the fact that even if the researcher has access to some information about the parents' socio-economic background, this information is often very scarce, and information about e.g. parental health status, marital history and behavior during pregnancy is often missing. Therefore, it is not possible to study the extent to which differences in outcomes between children with same-sex and children with opposite-sex parents are explained by socio-economic differences between their parents.

One way to overcome some of the problems with data limitations is to conduct surveys. However, such surveys also have their limitations since sample sizes often are too small to 
detect statistically significant differences, and that they also are based on non-representative samples. Furthermore, representative comparison groups are often missing.

The research closest to our study is three studies, and one reexamination, by Rosenfeld (2010), Allen et al. (2013), Allen (2013) and Reczek et al. (2016). The studies by Rosenfeld, Allen et al. and Allen focus on how children's educational outcomes are correlated with their parents' sexual orientation in the US and Canada respectively, while the study by Reczek et al. focuses on health outcomes among children with same-sex parents in the US.

To our knowledge, these are the only studies conducted on relatively large samples that also include informative comparison groups. The sample in the study by Rosenfeld (2010) consists of 3,502 children with same-sex parents. When Allen et al. (2013) re-examined Rosenfeld's study the sample restrictions were changed and the sample consisted of 8,632 children with same-sex parents. The sample in Allen (2013) consisted of 1,392 children with same-sex parents while a sample consisting of 633 children with same-sex parents were used in the study by Reczek et al. (2016). In fact, besides the studies mentioned, we are able to find very few other studies that are based on samples consisting of more than 100 children with samesex parents. In these studies comparison groups are either missing or very small. ${ }^{6}$

Rosenfeld (2010) used data from the 2000 US Census and studied differences in delayed progress through school (grade retention rates in elementary school) among children with different family structures. The study compared the outcome of children with same-sex parents with that of children with opposite-sex parents (married, remarried, and single). The identification of same-sex parents and opposite-sex parents was made possible by the fact that family structure was self-reported in the Census. In order to create a measure of same-sex and opposite-sex parents, children and parents who had been co-resident for at least five years

\footnotetext{
${ }^{6}$ An overview of the studies is given by Allen (2013).
} 
prior to the study were included in the sample. Thus, children who had been co-resident with same-sex parents during the last five years prior to the time of the study were classified as children of same-sex parents. A risk of misclassification is then obvious since children who were co-resident with same-sex parents by the time of the study and had been so for at least five years (classified as children of same-sex parents) might have grown up with opposite-sex parents during their earlier childhood. Rosenfeld then compared the outcome of children with same-sex parents with that of children with opposite-sex parents. Rosenfeld found no differences in retention rates between children with same-sex parents and children of with opposite-sex parents (married or remarried) and single parents.

Rosenfeld's results were called into question by Allen et al. (2013). Allen et al. (2013) was critical to the comparison groups and sample restrictions used by Rosenfeld (2010). Using data from the same source, Allen et al. (2013) reexamined Rosenfeld's study using alternative comparison groups and sample restrictions. When the comparison group was changed and the criteria that children and parents should have been co-resident for at least five years was relaxed, the results indicated that children of same-sex couples were more likely than children of opposite-sex couples to have delayed progress through school. However, the fact that children who were classified as children to same-sex parents by the time of the study might have grown up with opposite-sex parents during their earlier childhood was a potential bias also in the reexamination by Allen et al. (2013).

In a more recent study, Allen (2013) used data from the 2006 Canadian Census and focused on differences in the probability of completing high school education among children with different family structures, including the children of married opposite-sex couples, children of same-sex couples, and children of single parents. The study relied on a self-reported measure when same-sex and opposite-sex parents were identified. Children were asked if they were a child of a same-sex or an opposite-sex couple. Thus, Allen (2013) was able to distinguish 
between children of gays and lesbians in their sample. However, there was a limitation in the study by Allen as well, since no information about the extent to which the children in the study had been growing up with same-sex or opposite-sex parents during their childhood were available.

Allen's results showed that children living with same-sex parents in the year 2006 were less likely to complete high school education than children living in households with opposite-sex parents in that year. Furthermore, daughters of same-sex parents were less likely than sons to complete high school education.

Reczek et al. (2016) used data from the National Health Interview Survey (NHIS) in the US for the years 2004 to 2013 and studied physical as well as mental health outcomes among children with same-sex and opposite-sex parents. Different household types (married samesex, married opposite-sex, cohabitant same-sex and cohabitant opposite-sex) were asked questions about their children's health. The results showed that children with cohabiting parents had poorer health outcomes than children with married parents regardless of the sex composition of their parents. However, children in married same-sex households and children in married opposite-sex households had similar health outcomes and so had also children in cohabiting same-sex households when they were compared to children in cohabiting oppositesex households.

As mentioned, the studies presented are up to now the only ones based on relatively large and representative samples. However, there are limitations also in these studies. The probably most obvious limitation has to do with the identification of the children to same-sex parents. All the studies mentioned make use of self-reported identification and there is little, or no, information about the extent to which the children have grown up with their parents during 
their childhood. Besides this, the information about the parental generation is relatively scarce.

Against this background we are able to improve knowledge in this area in different important aspects. Firstly, we have access to data in which we have information about all children born by mothers who were living in same-sex marriages (or registered partnerships) no later than six months after the child's birth. Thus, we have reliable information about that the parents are in a sexual relationship when the child is born. For all those children we have access to information on health and educational outcomes. Furthermore, we are able to compare the outcomes for these children with the outcomes for all other children and different sub-groups thereof during the same period.

In our study we have access to data for 750 children with lesbian parents. We are able to track all these children and observe different outcomes through age 10. Furthermore, we have information about a rich number of background variables for the parental generation. Thereby, our study will contribute to the literature by using data lacking from the discussed weaknesses.

\section{The Swedish institutional set-up}

Sweden was one of the first countries in the world to allow homosexuals to enter registered partnerships and to become legal parents. Four institutional changes have extended rights for homosexuals to enter registered partnerships and marriages and to become parents from 1995 until today. An overview of these is given below.

\section{5 (January 1)}

The Registered Partnership Act took effect by January 1, 1995. It granted homosexuals in registered partnerships all rights provided to married heterosexual couples, with the important 
exception for the issue of parenthood. The left out of the paternity presumption implied that when a female individual in a registered partnership gave birth to a child the other female in the partnership did not become legal parent of the child. Furthermore, homosexuals in registered partnerships were not allowed to adopt a child neither jointly nor as stepparents. These forms of adoption were open to married heterosexuals only. However, the Registered Partnership Act expanded parenting ability for homosexuals in the sense that it allowed parental leave assigned to a parent to be shared between individuals in a partnership.

\section{3 (January 1)}

In 2003, the adoption law gave individuals in registered partnerships the same rights to adopt children as married heterosexuals. In Sweden, married heterosexual couples can adopt children jointly or as stepparents. A couple, married or in a registered partnership, can only adopt a child jointly when none of the individuals is a biological parent of the child. This possibility is limited for homosexuals since some countries do not allow adoption for samesex couples. A more relevant right for homosexuals is therefore the right to adopt as a stepparent. This implies that one of the individuals in the registered partnership is the biological parent to the child while the other person in the partnership adopts the child as a stepchild.

This right is more likely to be used by lesbian couples than by gay couples. One possibility is when two women are living in a registered partnership where one of the women is the biological mother to a child born before 2003. If the father is unknown, the other women can adopt the child as her stepchild. Another possibility is a couple with two women where one of the women becomes pregnant. If the biological father of the child relinquishes his parental rights, or if the biological mother declares the father unknown, the other women in the partnership can adopt the child as her stepchild. 
For obvious reasons, the introduction of the adoption law is less consequential for males than for females. If a man in a registered partnership has a child from a previous marriage, the mother of the child has to relinquish her parental rights for a stepparent adoption by the other man in the registered partnership to take place.

\section{5 (July 1)}

Homosexual women, in registered partnership or cohabiting, were given the right to artificial fertility treatment (insemination or IVF-treatment), through the national health care system. A necessary condition for such treatment, for homosexual as well as for heterosexual couples, is that the partner or cohabiting spouse formally agrees about the treatment. The form that must be used for such an agreement also stresses that the cohabiting partner becomes the legal parent of the child. In addition, a medical doctor, after having examined the couple's medical, psychological and social conditions in order to make sure that the child will grow up in good conditions, must formally agree about the chosen fertility treatment (insemination or IVFtreatment).

Up to 2005, the right to artificial insemination was reserved to married or cohabiting heterosexual couples. The right to artificial fertility treatment for cohabiting homosexual women thus implied that homosexual women no longer need to be in a registered partnership to become legal parents to a child.

\section{9 (November 1)}

In November 2009 registered partnership was replaced by same-sex marriage for homosexual individuals. Couples in a registered partnership were allowed to convert their partnership into a same-sex marriage. The change from registered partnership to marriage was not associated with any change in legal rights and obligations for homosexual individuals. The paternity presumption is still left out from the legal right included in same-sex marriage. 


\section{Data: sources and descriptives}

The starting point for the construction of our analysis sample is the total population of children born in Sweden during 1995-2010. Then we use Statistics Sweden's multigenerational register to identify the biological and adoptive parents of these children and add these parents to the data set. We obtain background information about the parents, such as their educational level, from other registers held by Statistics Sweden.

We use registers administered by the National Board of Health and Welfare to obtain our outcome measures of children's health. The Swedish Medical Birth Register contains data on birth weight reported by hospitals. This register also provides some information about mothers' behavior and health during pregnancy. The National Patient Register contains data on children's health. We observe health up to the age of 10, or the lower age they had reached by the end of 2014 .

Our school outcome variables come from Statistics Sweden's register over national tests in Mathematics and Swedish for pupils in the third grade. The tests are taken during the Spring semester of the third grade, i.e., during the calendar year when most pupils reach the age of ten. These tests are available for the total population of school children from 2010 and onwards. Thus, for our purposes, these data are only available for the cohorts born from 2000 to 2004 .

In order to define a child as having same-sex parents, we use Statistics Sweden's data on civil status; in Swedish register data, it is not possible to identify which adults cohabitate with whom. Our analysis focuses on children with lesbian parents. A child is considered to have had a lesbian mother if the biological mother entered registered partnership (through 2009), or married a same-sex partner (from November 1, 2009 onwards), no later than six months after 
the birth of the child. ${ }^{7}$ We want to allow the partnership or marriage to start six months after the birth of the child since it is common in Sweden to marry soon after the birth of the child. Since sample size is an issue for us, it is tempting to allow the partnership or marriage to start even later. However, in that case we may include children who have spent a considerable part of their childhood in another family type than the one we are interested in.

Table 1a reports the number of children, who have had lesbian parents according to our preferred, as well as alternative definitions. Only few children born in the very first years fulfill our preferred criteria of having lesbian parents, e.g., only 21 children born through 2001 fulfill the criteria. From then on, the number increases rapidly until 2010 when 196 children belong to our sample with lesbian parents. Considering that the size of a Swedish cohort is just above 100,000 , this number implies that close to two children out of thousand have lesbian parents. In all, 750 children (whereof 367 are boys and 383 are girls) are included in our main sample of children with lesbian parents.

The other columns to the right in the table show that a much larger number of children have a mother who later during the child's life has entered partnership or marriage. In particular, many more children born from 1992 to 2010 (1,888 children) have a biological mother who any time during our period of observation (through 2014) entered registered partnership or marriage with another women. This pattern, as well as the increase in the number of children over cohorts, suggests that registered partnership and same-sex marriages became increasingly popular over time. Both the recurrent reforms and general attitudes in society may explain the rise in popularity over time.

\footnotetext{
${ }^{7}$ Note that with this definition we do not include children with cohabiting lesbian parents of which one has agreed to artificial fertility treatment of the partner after 2005. The reason that we cannot include these children is that Statistics Sweden's research data base (the Multigenerational Register) does not identify parenthood via such agreement. This register only includes information about the child's biological mother and, if existing, the adoptive mother. Children with cohabiting lesbian parents are counted as "children with other parents" in our analysis.
} 
In a sensitivity analysis in section 6 , we apply the samples defined by the alternative time limits to examine the outcomes for children. The results show that the definition really matters; in particular the results using "60 months after the child's birth" and "any time" are different from the results we obtain for our preferred definition and sample.

In Table 1b, we report similar data for children with gay parents of which one is the biological father of the child. ${ }^{8}$ The samples are much smaller although the general trend towards larger numbers over time can be found here too. However, because of the small samples we do not consider outcomes for these children.

Table 2 reports the share of children with lesbian parents who also have a legal biological father. During the period 1995-2004 - before artificial fertility treatment was offered by the national health service - around half of all children with lesbian parents had a legal biological father. This share decreased to around 12 percent for the 2005-2010 cohorts. The table also shows that $0.5-0.8$ percent of all other children do not have a legal biological father. The share of children with a lesbian biological mother who also had an adoptive mother increased from around 25 percent for the 1995-2004 cohorts to around 50 percent for the 2005-2010 cohorts. Table 2 also reports that there are slightly more girls than boys who have lesbian parents in contrast to children with other parents (and married opposite-sex parents) where there is a slight majority of boys. However, treating the data as random samples, we cannot reject the null hypotheses that the proportion boys and girls are the same among children with lesbian parents as among children with other parents (or married opposite-sex parents). Table 3 reports some overall background statistics for lesbian parents and our two comparison groups of other parents. The first row shows that lesbian mothers, as expected, are older than other

\footnotetext{
${ }^{8}$ As matter of fact, there is some overlap between the data in Table $1 \mathrm{a}$ and $1 \mathrm{~b}$ since some children have both a lesbian biological mother and a gay biological father. In our main sample of 750 children, 15 children are classified as having both a lesbian biological mother and the gay biological father. This amounts to only 2 percent of the children with lesbian mothers but over $40 \%$ of the children with a gay biological father.
} 
mothers at the birth of the child, the difference is around 3 years for all other mothers and around 2 years for mothers in opposite-sex marriages. There are no teenage mothers among the lesbian mothers in contrast to around 1.2 percent among all other mothers.

There are also clear differences in season of birth between lesbian and other mothers. The second and third quarters are the peaks for most births in Sweden with the fourth quarter as the bottom. In contrast, the fourth quarter is the peak for lesbian mothers. We cannot say whether this is due to parental preferences or, e.g., service constraints at the medical hospitals that provide fertility treatment.

Lesbian parents have higher education than other parents. This advantage is evident in both the bottom and the top of the distribution of education. It is less common that lesbian birth mothers are born abroad than is the case for other mothers. Further, lesbian mothers do more often live in metropolitan areas than other mothers.

Finally, we note that children with lesbian parents have clearly fewer older siblings born or adopted by the birth mother. Whereas those with other mothers on average have around 0.50.6 , older siblings, children with lesbian parents have only around 0.15 older siblings on average. From 2005 and onwards, when the IVF-technique had improved, children with lesbian parents were clearly less likely to be a twin than other children.

\section{Results}

In our main analysis in this paper, we compare the outcomes of children with lesbian parents with two other groups of children. First, we compare with children who were born by married two-sex parents. For this comparison group, we apply a definition of marriage that corresponds to our definition for children with lesbian parents, namely that the parents were married at the birth of the child or got married no later than six months after the birth. The rationale for using such a comparison group is not that we consider such births as reasonable 
counterfactuals in case the new legislation had not been implemented. As a matter of fact, results in Aldén et al. (2015) suggest that the new legislation raised fertility. However, in the political debate, such families are often characterized as the ideal ones that policy should support and strive for. Further with such a comparison, we make a cleaner comparison of parenting behavior in two-sex and same-sex families (see Biblarz and Stacey, 2010).

Second, we compare the outcomes of children with lesbian parents with the outcomes of all other children. Our motivation for this comparison group is that the children of lesbian parents will grow up under a set of circumstances that differ from those of other children. We want to examine the combined impact of these circumstances on children's health and school outcomes. To the extent that these children would not have been born without the new legislation, it is natural to have all other children as comparisons for claims about good or bad outcomes.

For both comparison groups we use a regression framework in which we step-by-step add control and mediating variables to learn about the mechanisms that drive differences between our groups of children. We start by examining birth weight. Then we go on with health outcomes through age 10; here we conclude by controlling for birth weight to find out whether there are groups differences in addition to those generated by differences in birth weight. Finally, we investigate differences in school performance at age 10; here we conclude by controlling for both birth weight and health.

We use a combined sample of boys and girls and apply the following regression framework to study the impact of growing up with lesbian parents

$$
Y_{i}=\alpha_{0}+\alpha_{1}(\text { LPxBoy })_{i}+\alpha_{2}(\text { LPxGirl })_{i}+\alpha_{3} \operatorname{Girl}_{i}+\beta X_{i}+\varepsilon_{i}
$$


where $Y_{\mathrm{i}}$ denotes the outcome of interest for child $i, L P_{i}$ denotes having lesbian parents, $X_{i}$ is the set if control and mediating variables that we include step-wise in a series of estimations, and $\mathrm{e}_{i}$ is an error term.

The null hypothesis of no difference between children with lesbian parents and other children is that $\alpha_{1}$ and $\alpha_{2}$ are simultaneously zero. We report F-statistics for this null hypothesis. We also report F-statistics for the null hypothesis that $\alpha_{1}=\alpha_{2}$, i.e., that the gender gap among children with lesbian parents is the same as among other children.

\section{Birth weight}

Table 4 reports descriptive statistics for the birth weight variable. Sample 1 is or our main sample that we use throughout the paper for birth weight, health and school outcomes. Sample 2 is a subsample that we also use in this section for a more detailed analysis of the determinants of birth weight.

In Sample 1, the differences in birth weight between children with lesbian parents and the two other larger groups are small, albeit with lower mean birth weight for children with lesbian parents. For both boys and girls, the difference is clearly below 100 grams for all comparisons in the table. We use the fraction of children born with low birth weight $(<2500 \mathrm{~g})$ and the tenth percentile (Q10) to focus on the lower part of the birth weight distribution. For the cohorts born 2005-2010, to which most of the observations of children with lesbian parents belong, the corresponding differences can be found. However, girls with lesbian parents deviate more than boys by having lower birth weight and low Q10-values. For the cohorts born 1995-2004 children with lesbian parents reveal a lower fraction with low birth and higher Q10-values than the broader groups but here the frequency of children with lesbian parents is low. 
Sample 2 also contains additional variables from the Medical Birth Register that we use to study variables that potentially can mediate the relationship between family structure and birth weight. These variables suffer from non-response so this sample is smaller and potentially suffer from some sample selection bias when it comes to our issues; the nonresponse rate is around 14 percent.

The data on birth weight in Table 4 suggest that the non-response is somewhat selective with respect to the group differences in birth weight, in particular for boys in the cohorts 20052010. While the mean, Q10-value and share with low birth weight is about the same for the groups with other parents and opposite-sex parents in the two samples, the Q10-value is almost 100 grams higher for boys with lesbian parents in sample 2 compared to sample 1. And the share with low birth weight is only 0.024 in sample 2 compared to 0.051 in sample 1 . This selective pattern does not necessarily rule out that sample 2 is informative about the mediating role of the additional variables from the maternity clinics that this sample contains.

Table 5 reports descriptive statistics for the additional variables provided by the Medical Birth Register. The first row shows that receipt of any type of fertility treatment is much more common among lesbian parents than among other parents and married opposite-sex parents. This variable is based on interviews with the pregnant mother and not on register information about actual treatments in the health care system. It seems more likely that mothers underreport than overreport such treatment, so we expect that this variable may underestimate the prevalence of fertility treatment.

We use information about BMI from the maternity clinics to construct three variables, namely BMI, overweight (BMI between 25 and 29.9) and obesity (BMI larger than on equal to 30). Such a variable is likely to capture health behavior close to and during pregnancy. The overall pattern, however, is that the three groups of parents are quite similar in this respect. There is, 
however, a considerable difference in smoking behavior among the three types of parents. For example, while only around 2 percent of lesbian mothers in 2005-2010 were smokers, the corresponding number for other mothers was 7 percent. Although most mothers do not smoke, this group difference could indicate that lesbian mothers also in other respects behave healthier than other mothers during pregnancy.

Table 6 and 7 report a set of regressions based on sample 1 with the logarithm of birth weight (OLS) and the probability of having low birth weight (Linear probability models, LPM) as dependent variables. The tables contain separate results for all other children and children with married two-sex parents respectively as comparison groups. However, the results are very similar for these two comparison groups so we comment only on the results with all other children as comparison.

We start (in column 1) by controlling for the child's birth year in order to account for a possible nation-wide trend in birth weight. ${ }^{9}$ We consider the coefficients in this column as unconditional differences between the groups. The coefficient in Table 6 for girls is -.025 and weakly significant from zero, indicating that girls with lesbian parents on average have 2.5 percent lower birth weight than girls with other parents. The coefficient for boys is almost the same, namely -0.023 . Next, we add three indicators of socio-economic status, namely the biological mother's education, region of residence and immigrant status. These coefficients are significant as main effects (not reported but available from the authors upon request). For example, children of mothers with long university education have around 2.1 percent higher birth weight than children of mothers with only compulsory education. Further, children with mothers born abroad have around 3.1 percent lower birth weight, and the differences between

\footnotetext{
${ }^{9}$ The regression results that we present in these and subsequent tables are of course sensitive to the order in which we enter the control variables. We argue that the chosen order follows a logical causal sequence. The first controls for birth year represent background population characteristics, the second set of controls for socioeconomic status represent background factors that have an impact on fertility planning and behavior during pregnancy, the number of older siblings are pre-determined variables relative to the occurrence of multiple births.
} 
high and low birth weight counties are also around 3 percent. The two coefficients for having lesbian parents become slightly more negative when the mediating effects of these socioeconomic status variables are netted out.

Next (in column 3), we add variables for mother's age at the birth of the child. The two key coefficients are basically unaffected. The same conclusion follows from column 4 where we also have included child's quarter of birth. These results are not surprising since, for example, having a teenage mother is not associated with a different birth weight and the differences by birth quarter are small as well.

In column 5, we add the number of older siblings, a variable that, of course, is zero for firstborn children. Now, the two key coefficients are cut in half and they are no longer significant. The reason is that we now control for a variable with a positive main effect (each additional older sibling predicts a higher birth weight by 3.0percent), and children with lesbian parents have fewer older siblings. Thus, when we control for this negative factor among children with lesbian parents, they come closer to other children in terms of birth weight.

Finally, in column 6, we also add a control for multiple births, which are associated with $0.350 \log$ points lower birth weight. Considering that multiple births are much less common among children with lesbian mothers, these children benefit in terms of birth weight from less frequent multiple births. When we account for the negative effect of multiple births, the direct effect becomes more negative and is again significant for both boys and girls.

To summarize these results, we have found that both boys and girls with lesbian parents have, on average, around 2.4 percent lower birth weight than other children. One circumstance tends to drive birth weight down for this group, namely the fact they have fewer older siblings (and tend to be the first-born child). On the other hand, two circumstances help children with lesbian parents to keep birth weight up, namely that they have a more favorable socio- 
economic background and less often have a twin sibling. Since the coefficients in column 6 are very close to those in column 1 , these three circumstances more or less balance each other.

Table 7 reports the corresponding estimates for the probability of having low birth weight. The unconditional differences in column 1 show, as expected from the previous results, that children with lesbian parents more frequently have low birth weight. However, only the coefficient for girls is significantly different from zero, and the coefficients for boys and for girls are close to significantly different from each other (p-value 0.126$)$. These baseline coefficients change in the same way as above when we include mediating factors in the remaining columns. The coefficients increase somewhat when we control for socio-economic status, decrease when we control for number of older siblings and increase again when we account for multiple births. The coefficients in column 6 are very close to those in column 1 .

We now turn to Table 8 and 9 where we use sample 2 and the additional variables in the Medical Birth Register. As expected from the descriptive information in Table 4, the coefficients for boys with lesbian parents now are more favorable in terms of birth weight, whereas the coefficients for girls are more similar to the previous ones. In columns 2, 3 and 4 we add, as before, in turn socio-economic status variables, mother's age at the birth of the child and child's quarter of birth. As before the variables for socio-economic status matter a bit suggesting that children of lesbian parents gain from their parents socio-economic status.

In column 5 we add a variable for "any fertility treatment". The main coefficient for fertility treatment is -0.079 for $\log$ birth weight and 0.072 for the share with low birth weight. These coefficients, which are estimated with high precision, are quite substantial in magnitude. Further, we saw in Table 5 that fertility treatment is much more common among lesbian parents. Thus, as expected, the key coefficients for having lesbian parents fall markedly when we move from column 4 to column 5 . When controlling for fertility treatment in column 5 , 
the only significant coefficient for lesbian parents is the one for boys and low birth weight which is -0.031 . This result suggests that fertility treatment tends to drive birth weight down for children with lesbian parents.

The next two columns account for mother's BMI and smoking habits. The key coefficients are basically unaffected. The reason that the lower prevalence of smoking among lesbian mothers does not mediate any substantial effects on birth weight is probably that the overall prevalence of smoking is quite low.

Finally, as before, we add variables for the number of older siblings (column 8) and multiple birth (column 9). The key coefficients change as before in Table 6 and 7. Controlling for the negative factor of having a larger number of older siblings makes the outcomes children with lesbian parents more favorable, whereas controlling for multiple birth makes the outcome less favorable.

We have also performed a number of sensitivity tests to see whether our results are sensitive to some quite arbitrary decisions that we have made. ${ }^{10}$ First, we raised the lower limit of having low birth weight to 2,600 and 2,700 grams respectively. Because the share of children with a birth weight below 2,500 grams is quite low, the estimates may be sensitive to this limit. However, our estimates changed at most one standard error when we raised the limits. Second, we estimated our equations on the cohorts born 2005-2010 since fertility treatment technology and institutions changed in 2005. Again, the key estimates turned out to be very robust.

\section{Health}

We use two health outcomes. We focus on diseases of the respiratory system up to the age ten, since such diseases at young ages may be a result of the mothers' habits (smoking etc.)

\footnotetext{
${ }^{10}$ These estimates are available upon request.
} 
during pregnancy. The outcomes are objective diagnoses made by doctors after that medical care have been sought for the child. The first measure, Diseases of the respiratory system, reflects such diagnoses that require hospitalization. The second measure, Avoidable diseases of the respiratory system, reflects less severe diagnoses that do not require hospitalization. In particular, these are diseases that could have been avoided by cautious parenting (see Page et al. 2007, and note $b$ in Table 10).

In Table 10 we report descriptive statistics for these health measures as well as two sibling variables that we use in this analysis. The prevalence of the broader measure in the largest group (with "other parents") is just above 10percent for boys and around 7.5percent for girls. The corresponding numbers for the more narrow measure are 4.2 percent for boys and 2.8 percent for girls. Again, the prevalence is almost the same among children with "married opposite parents as among children" with "other parents". Children with lesbian parents deviate from these patterns in a gender-specific way. For the broader measure, boys with lesbian parents have around 3 percentage points lower prevalence of this disease compared to most children, whereas girls with lesbian parents have higher prevalence ( 2.4 percent for the 2005-2010 cohorts). This pattern is less clear for the second more narrow measure of diseases of the respiratory system.

For this analysis, we include a variable for the number of older siblings (as above for birth weight) as well as the number of younger siblings (here defined at age 4). Children with lesbian parents have fewer older as well as younger siblings.

Table 11 reports our regression results for the broader measure. The first column, with controls only for the child's birth year, confirms the descriptive differences in the previous table. The LPM-coefficients for boys and girls with lesbian parents are -0.034 and 0.024 respectively. The null hypothesis that these two coefficients are simultaneously zero is 
strongly rejected and the same applies to the null-hypothesis that these coefficients are the same for boys and girls.

In column 2, we control for mother's socio-economic status. Since our health measure has the usual social gradient, coefficients becomes higher but only marginally so. In columns 3 and 4, we add controls for mother's age at the birth of the child as well as child's birth quarter. These variables do not change the key coefficients. Next in column 5, we add variables for the number of older and the number of younger siblings. Our coefficients of interest increase, but only marginally. We add multiple birth in column 6 without finding any substantial impact on the key coefficients. Yet, the main coefficient for multiple birth is 0.037 with a trivial standard error. Finally, in column 7, we add two birth weight variables - a linear variable for birth weight and a dummy for low birth weight - without any marked impact on the coefficients. The main effects of these birth weight variables on this health outcome are quite substantial with a coefficient of 0.046 for low birth weight. Yet birth weight does not mediate any substantial effects of having lesbian parents on health. The reason must be that the differences in birth weight between children with lesbian parents and children with other parents are too small to create any such effects.

In Table 12 we report our regression estimates for the more narrow health measure that only includes the "avoidable" diseases of the respiratory system. The most striking pattern in these results is that the coefficients for boys and girls with lesbian parents are very close to zero and estimated with a reasonably low standard error of around 0.01 . These results suggest that the differences observed for the broader health measure are due to underlying biological differences rather than parenting.

We have also performed a sensitivity test to see whether our results are affected by the time limits used to construct the health outcomes measure. When we included diseases up to the 
age of 19, nothing substantial happened to the estimated key coefficients in Table 11 and 12 . Further, we have investigated whether parental divorce is an important mediator; this analysis can only be done for children with married opposite-sex parents. We found that divorce is much more common among children with lesbian parents and that there is a significant main effect on our broad health measure of 0.013 . Nevertheless, these differences are not strong enough to produce any substantial mediating effects of parental divorce.

\section{School performance}

In the Spring semester of the third grade, all pupils in Swedish schools are subject to compulsory national tests in Mathematics and Swedish. This is in the calendar year when most pupils reach the age of ten. The tests in each subject consist of a series of subtests. On each subtest, the central school authority has specified a level that is considered to meet the politically determined minimum skill requirements. For a few of the subtests, the only information that is collected is whether these requirements are met or not. Out of this information, we define two outcome measures in each subject. The first one we call "pass" and equals one if the pupil has met the minimum requirements on all subtests, zero otherwise. The second one is the average percentile score on the subtests for which information on scores (the number of correct answers) is available.

These national tests cannot be considered high-stake tests from the point of view of the pupil. At this age, Swedish pupils are not formally graded and tracking will not take place until age 16. However, the results are important for schools who must take action when pupils do not meet the minimum requirements. Further, the test results are reported to parents for whom the results are the first quantitative signals about if their children's school performance.

Table 13 reports descriptive statistics for these school variables and the new variables that we use in the regressions. Because the national-test information is available only from 2010-2014 
(cohorts 2000-2004), the sample size is much smaller for this analysis. Only 26 boys and 30 girls with lesbian parents are included in this sample. The overall pattern is that children with lesbian parents are doing better than other children (or with married opposite-sex parents). In Math, boys with lesbian parents have almost 9 percentiles higher average rank than boys with other parents, and the fraction with pass is 0.846 compared to 0.732 . The Math performance of girls with lesbian parents is more similar to girls with other parents. In Swedish, both boys and girls with lesbian parents do better than those with other parents. In terms of percentiles, they are around 10 points ahead of other children.

We report the regressions for Math in Table 14 and 16. The point estimates for boys with lesbian parents are high, 0.130 higher probability of getting a pass and 8.8 percentiles higher overall results compared to all other children. For girls with lesbian parents, the estimates are practically close to zero. As expected, however, the precision of these estimates is low so much caution is called for when interpreting these results. Despite the really high point estimates for boys, the estimates are only borderline significant at conventional levels. Thus, confidence intervals based on these estimates become wide.

When we add mediating variables as controls there is only one set of variables that matter, namely mother's socio-economic status (column 2). The positive coefficients for boys are reduced by more than one third when these variables are added. This is not surprising since school outcomes have a strong socio-economic gradient. The other variables, however, do not matter much. These are mother's age at the birth of child (column 3), child's birth quarter (column 4), number of older and number of younger siblings (column 5), multiple birth (column 6), birth weight (column 7) and the two health indicators (column 8). The main effects of these variables are strongly significant and of a substantial magnitude, for example children born in the fourth quarter have 4.5 percentile points lower test scores than children 
born in the first quarter. Yet, these effects in combination with the group differences in the magnitude of these variables are not large enough to mediate effects of any important size.

The results for Swedish (Table 15 and 17) are quite similar for boys with lesbian parents but now the effects are positive also for girls with lesbian parents, in particular when the percentile rank is used as the outcomes variable. The point estimates for the percentile rank is 10.9 and 8.0 for boys and girls respectively. The standard errors are high but each coefficient is significantly different from zero at the 5 percent level and the null hypothesis that both coefficients are zero is strongly rejected (p-value 0.001$)$. The point estimates for the probability of getting a pass are positive for both boys and girls with lesbian parents but not significantly different from zero.

Our analysis of mediating factors tells the same story as the analysis of Math. The point estimates shrink by a third or more when we account for mother's socio-economic status but nothing important happens when we add the other variables. For Swedish, the birth quarter of the child matters even more with a main effect of -5.5 for children born in the fourth quarter compared to children born in the first quarter. Birth weight and health also matter in the expected direction. For example, our broader health measure has a strongly significant main effect of -1.1 for both Math and Swedish.

\section{Sensitivity analysis}

Our definition of children with lesbian parents is arbitrary in the sense that we require that the biological mother must have entered partnership or marriage with another women no later than six months after the birth of the child. Since our analysis suffers from small samples and large standard errors, it is tempting to apply a broader definition so that more children are classified as having lesbian parents. 
Table 18 and 19 report estimates that show what happens when we apply a more strict definition and a number of less strict definitions. We report estimates for all our outcomes measures but only for our unconditional model with controls only for year of birth (column 1 above) and our model with controls from mother's socio-economic status (column 2 above).

The first column reports estimates for the more strict definition, namely when we require that the biological mother had entered partnership or marriage at the birth of the child. A comparison of the estimates in this column and the baseline ones in column 2 shows that there are very small differences; the sample of children with lesbian parents is only reduced from 750 to 692 when the definition is changed is this way. Turning to the less strict definitions, the estimates tend to change only when we go to a period of "within 60 months" or "any time". The standard errors are generally much lower and often cut into half of the ones for our baseline definition. However, because the point estimates change markedly when we move from our baseline to the least strict definitions of being a child with lesbian parents, it would be misleading to use these estimates. Further, the changes in the point estimates go in different directions. The birth weight outcomes for boys improve (becomes less negative) when we move away from the baseline definition, whereas the positive health outcomes for boys disappear when we move away from this definition. Further, especially for boys the positive school outcomes more or less disappear. Our conclusion is that the definition is of being a child with lesbian parents is important in this field of research.

\section{Conclusions and discussion}

We started by looking at differences in birth weight between children with lesbian parents and children with other parents (or with married same-sex parents). Our estimates show that children with lesbian parents start their lives with an around 2.4 percent disadvantage in terms of birth weight; this difference was significantly different from zero at the five percent level. 
For girls, but not for boys, this difference also translates into a significantly higher proportion with low birth weight ( $<2.5$ kilos). Our analysis of mediating factors suggests that the much more frequent use of fertility treatment among lesbian parents can explain about half of this difference.

The natural question to ask about these estimated differences is whether they are to be considered large or small. A recent study by Bharadwaj et al. (forthcoming) use Swedish data to estimate the long-run effects of birth weight on permanent income during adulthood. They use twin-differences to obtain estimates that are more likely to be causal effects of birth weight. They estimate an elasticity of log birth weight with respect to log permanent income of 0.10 . Applying this elasticity on our 2.4 percent estimate suggests that the children of lesbian parents would have a 0.24 percent lower permanent income. Although this may amount to a non-trivial sum of money, it represents a very small difference in the distribution of permanent income. Indeed, Nybom and Stuhler (2016) report that the standard deviation of log permanent income is as high as 0.40 in Sweden.

When we observe health (diseases of the respiratory system) and school outcomes at age ten, these initial negative differences observed at birth turn into more positive ones. For boys with lesbian parents, we observe a significantly lower prevalence of such diseases (-3.4 percentage points $)$, whereas the prevalence for girls with lesbian parents is higher $(+2.4$ percentage points) but not significantly higher. The same group and gender differences are found for school outcomes. Tests scores in Math and Swedish of boys with lesbian parents are on average as much as 10 percentile points better than for boys with other parents. However, due to the smaller sample that we must use for school outcomes these differences are only barely significantly different from zero. For girls, differences in school outcomes are smaller and not significantly different from zero. 
For all three outcomes, our analysis of mediating variables shows that children with lesbian parents, compared to other children, benefit from their mother's socio-economic status in which we include the biological mother's education, region of residence and immigration status. Thus positive differences are smaller and negative differences are larger when we add controls for these socio-economic status variables. However, our mediating analysis cannot explain why the initial negative differences in terms of birth weight are turned into more positive differences around age ten. Neither do we have a good explanation to the gender pattern in our results, namely that boys with lesbian parents seem to do better than boys whereas there is no such pattern among girls.

It is, however, possible to use our results and results from the previous literature to speculate about reasons for the more positive differences around age ten. Our data from the Medical Birth Register show that lesbian mothers smoked less during their pregnancy than other mothers. If this more healthy and cautious behavior continued when the child grew up, it is reasonable that the child would benefit in terms of health and school outcomes. Further, in their survey, Biblarz and Stacey (2010), report that available (though few) studies suggest that lesbian parents reveal a higher desire to have a child and spend more time with their children.

Obviously, our analysis suffers from the low number of children with lesbian parents, and the even lower number of children with gay parents made us abstain from an analysis of this group. The rapid rise of such children during the last years of our study period will make it easier to estimate differences between children with same-sex parents and other children (or subgroups of other children) during the years to come. In particular, it would be interesting to do the analysis of school outcomes with a larger number of observations to see whether the quite substantial differences suggested by our point estimates will hold up in a larger sample. This said, it is also important to stress that the attitudes towards homosexuals in general and to homosexuals having children in particular become more and more tolerant over this period of 
time. Thus, the underlying differences between children with same-sex parents and other parents may also have changed.

Finally, we want to stress that our comparisons of children with lesbian parents and children with other parents refer to Sweden and that they are not necessarily applicable to other countries. Indeed, the questions about attitudes to homosexuals in the European Values Study, show that Sweden (from the first wave in 1981 and through 2008) has the most positive attitudes towards homosexuals among European countries. ${ }^{11}$ Further, the data in this survey for the United States places this country on the lower half among European countries in such attitudes. Nevertheless, we believe that the discussion about rights for homosexual couples in many countries would benefit from noting that children with lesbian parents in Sweden in terms of health and school performance do not fare very differently from other children.

\footnotetext{
${ }^{11}$ See Diaz-Serrano and Meix-Llop (2016) and www.europeanvaluesstudy.eu/.
} 


\section{References}

Ahmed, Ali, Lina Andersson and Mats Hammarstedt (2008) "Are Lesbians Discriminated on the Rental Housing Market? Evidence from a Correspondence Testing Experiment", Journal of Housing Economics, 17, 234-238.

Ahmed, Ali, Lina Andersson and Mats Hammarstedt (2011), "Inter- and Intra-household Earnings Differentials Among Homo- and Heterosexual Couples", British Journal of Industrial Relations, 49, s258-s278.

Ahmed Ali, Lina Andersson and Mats Hammarstedt (2013), "Are Gay Men and Lesbians Discriminated Against in the Hiring Situation?", Southern Economic Journal, 79, 565-585.

Ahmed, Ali and Mats Hammarstedt (2009), "Detecting Discrimination Against Homosexuals: Evidence from a Field Experiment on the Internet", Economica, 76, 588-597.

Ahmed Ali and Mats Hammarstedt (2010), "Sexual orientation and earnings: a register databased approach to identify homosexuals", Journal of Population Economics, 23, 835-849.

Aldén, Lina, Lena Edlund, Mats Hammarstedt and Michael Mueller Smith (2015), "Effect of Registered Partnership on Labor Earnings and Fertility for Same-Sex Couples: Evidence from Swedish Register Data”, Demography, 52, 1243-1268.

Allen, Douglas W. (2013), "High School Graduation Rates Among Children of Same-Sex Households", Review of Economics of the Household, 11, 635-658.

Allen, Douglas W., Catherine Pakaluk and Joseph Price (2013), "Nontraditional Families and Childhood Progress Through School: A Comment on Rosenfeld", Demography, 50, 955-961.

Almond Douglas and Janet Currie (2011), "Killing Me Softly: The Fetal Origins Hypothesis, Journal of Economic Perspectives, 25, 153-172.

Andersson, Gunnar, Turid Noack, Ane Seierstad and Harald Weedon-Fekjaer (2006), "The Demographics of Same-Sex Marriages in Norway and Sweden", Demography, 43, 79-88.

Bharadwaj, Prashant, Petter Lundborg and Dan-Olof Rooth (2017), "Birth Weight in the Long Run", Journal of Human Resources, forthcoming.

Biblarz Timothy J. and Judith Stacey (2010), "How Does the Gender of Parents Matter?", Journal of Marriage and Family 72, 3-22.

Black, Sandra E, Paul J Devereux and Kjell G Salvanes (2005), "The More the Merrier? The Effect of Family Size and Birth Order on Children's Education", The Quarterly Journal of Economics 120, 669-700.

Diaz-Serrano, Luis and Enric Meix-Llop (2015), "Do schools discriminate against homosexual parents? Evidence from a randomized correspondence experiment", Economics of Education Review, 53, 133-142.

Hammarstedt, Mats, Ali M. Ahmed and Lina Andersson (2015), "Sexual Prejudice and Labor Market Outcomes for Gays and Lesbians: Evidence from Sweden", Feminist Economics, 21, 90-109.

Kolk, Martin and Gunnar Andersson (2016), "Two Decades of Same-sex Marriage in Sweden: A Demographic Account", paper presented at the 2016 meeting of the Population Association of America. 
Marks, Loren (2012), "Same-Sex Parenting and Children's Outcomes: A Closer Examination of the American Psychological Association's Brief on Lesbian and Gay Parenting”, Social Science Research, 41, 735-751.

McLanahan, Sara, Laura Tach and Daniel Schneider (2013), "The Causal Effects of Father Absence", Annual Review of Sociology, 39, 399-427.

Nilsson, Peter (2017), “Alcohol Availability, Prenatal Conditions, and Long-term Economic Outcomes", Journal of Political Economy, forthcoming.

Nybom, Martin and Jan Stuhler (2016), "Heterogenous Income Profiles and Lifecycle Bias in Intergenerational Mobility Estimation “, Journal of Human Resources, 51, 239-268.

Page, Anthea, Sarah Ambrose, John Glover, and Diana Hetzel (2007) "Atlas of Avoidable Hospitalizations in Australia: ambulatory care-sensitive conditions", Adelaide: PHIDU, University of Adelaide.

Reczek, Corinne, Russell Spiker, Hui Liu and Robert Crosnoe (2016), "Family Structure and Child Health: Does the Sex Composition of Parents Matter?", Demography, 53, 1606-1630.

Rosenfeld, Michael J. (2010), "Nontraditional Families and Childhood Progress Through School”, Demography, 47, 755-775.

Tasker, Fiona (2010), "Same-sex Parenting and Child Development: Reviewing the Composition of Parental Gender", Journal of Marriage and Family, 72, 35-40.

Templeton, Allan, Joan Morris and William Parslow (1996), "Factors That Affect Outcomes in In-Vitro Fertilization Treatment", The Lancet, 348, 1402-1406. 


\begin{tabular}{|c|c|c|c|c|c|c|}
\hline $\begin{array}{l}\text { Child's year of } \\
\text { birth }\end{array}$ & At child's birth & $\begin{array}{l}\text { Within } 6 \text { months } \\
\text { after child's birth }\end{array}$ & $\begin{array}{l}\text { Within } 12 \text { months } \\
\text { after child's birth }\end{array}$ & $\begin{array}{l}\text { Within } 36 \text { months } \\
\text { after child's birth }\end{array}$ & $\begin{array}{l}\text { Within } 60 \text { months } \\
\text { after child's birth }\end{array}$ & Any time \\
\hline 1992 & 0 & 0 & 0 & 1 & 2 & 70 \\
\hline 1993 & 0 & 0 & 0 & 0 & 2 & 69 \\
\hline 1994 & 0 & 0 & 0 & 2 & 3 & 71 \\
\hline 1995 & 0 & 0 & 0 & 1 & 4 & 77 \\
\hline 1996 & 2 & 2 & 2 & 4 & 7 & 65 \\
\hline 1997 & 5 & 5 & 6 & 8 & 9 & 65 \\
\hline 1998 & 0 & 0 & 0 & 1 & 4 & 59 \\
\hline 1999 & 3 & 3 & 3 & 4 & 6 & 54 \\
\hline 2000 & 7 & 7 & 8 & 11 & 13 & 75 \\
\hline 2001 & 3 & 4 & 4 & 6 & 8 & 65 \\
\hline 2002 & 11 & 11 & 13 & 19 & 22 & 79 \\
\hline 2003 & 17 & 19 & 19 & 23 & 27 & 66 \\
\hline 2004 & 19 & 20 & 22 & 21 & 28 & 67 \\
\hline 2005 & 31 & 32 & 35 & 40 & 44 & 91 \\
\hline 2006 & 68 & 69 & 69 & 77 & 86 & 118 \\
\hline 2007 & 90 & 96 & 101 & 114 & 126 & 164 \\
\hline 2008 & 117 & 124 & 127 & 145 & 158 & 189 \\
\hline 2009 & 141 & 162 & 170 & 194 & 203 & 220 \\
\hline 2010 & 178 & 196 & 201 & 213 & 216 & 224 \\
\hline$N$ & 692 & 750 & 780 & 884 & 968 & 1,888 \\
\hline$N$ (boys) (girls) & $(337)(355)$ & $(367)(383)$ & (378) (402) & (437) (447) & (480) (488) & $(947)$ \\
\hline
\end{tabular}

Notes: The children are defined as children with lesbian parents based on the timing of the biological mother's entry into marriage or partnership relative to the child's birth. 
Table 1b. Number of children with gay parents by time of biological father's marriage (or partnership) since birth of the child.

\begin{tabular}{|c|c|c|c|c|c|c|}
\hline $\begin{array}{l}\text { Child's year of } \\
\text { birth }\end{array}$ & At child's birth & $\begin{array}{l}\text { Within } 6 \text { months } \\
\text { after child's birth }\end{array}$ & $\begin{array}{l}\text { Within } 12 \text { months } \\
\text { after child's birth }\end{array}$ & $\begin{array}{l}\text { Within } 36 \text { months } \\
\text { after child's birth }\end{array}$ & $\begin{array}{l}\text { Within } 60 \text { months } \\
\text { after child's birth }\end{array}$ & Any time \\
\hline 1992 & 0 & 0 & 0 & 0 & & 30 \\
\hline 1993 & 0 & 0 & 0 & 2 & 2 & 24 \\
\hline 1994 & 0 & 1 & 2 & 2 & 3 & 42 \\
\hline 1995 & 0 & 0 & 0 & 0 & 0 & 23 \\
\hline 1996 & 1 & 1 & 1 & 1 & 2 & 18 \\
\hline 1997 & 0 & 1 & 2 & 0 & 0 & 25 \\
\hline 1998 & 0 & 0 & 0 & 0 & 0 & 9 \\
\hline 1999 & 0 & 0 & 0 & 0 & 1 & 16 \\
\hline 2000 & 2 & 2 & 2 & 2 & 7 & 25 \\
\hline 2001 & 1 & 2 & 3 & 4 & 5 & 17 \\
\hline 2002 & 4 & 4 & 4 & 5 & 5 & 17 \\
\hline 2003 & 0 & 0 & 0 & 1 & 1 & 9 \\
\hline 2004 & 3 & 3 & 3 & 4 & 4 & 12 \\
\hline 2005 & 3 & 3 & 3 & 3 & 3 & 6 \\
\hline 2006 & 5 & 3 & 5 & 6 & 8 & 12 \\
\hline 2007 & 1 & 3 & 1 & 1 & 3 & 7 \\
\hline 2008 & 5 & 5 & 5 & 7 & 7 & 12 \\
\hline 2009 & 2 & 3 & 3 & 4 & 5 & 13 \\
\hline 2010 & 5 & 6 & 7 & 10 & 10 & 15 \\
\hline$N$ & 32 & 37 & 41 & 52 & 66 & 332 \\
\hline$N$ (boys) (girls) & (19) (13) & (23) (14) & $(26)(15)$ & (32) (20) & (37) (29) & (154) \\
\hline
\end{tabular}

Notes: The children are defined as children with gay parents based on the timing of the biological father's entry into marriage or partnership relative to the child's birth. 
Table 2. Share of children with a legal biological father or an adoptive mother, by birth cohort.

\begin{tabular}{lcccccc}
\hline & \multicolumn{2}{c}{ Lesbian parents } & \multicolumn{2}{c}{ Other parents } & \multicolumn{2}{c}{$\begin{array}{c}\text { Married opposite-sex } \\
\text { parents }\end{array}$} \\
\cline { 2 - 7 } & Boys & Girls & Boys & Girls & Boys & Girls \\
\hline $\begin{array}{l}\text { Share of children with a } \\
\text { legal biological father }\end{array}$ & & & & & & \\
1995-2004 & 0.576 & 0.447 & 0.995 & 0.995 & 0.998 & 0.998 \\
2005-2010 & 0.108 & 0.128 & 0.992 & 0.992 & 0.996 & 0.996 \\
$\begin{array}{l}\text { Share of children with an } \\
\text { adoptive mother }\end{array}$ & & & & & & 0.000 \\
1995-2004 & 0.273 & 0.263 & 0.000 & 0.000 & 0.000 & 0.000 \\
2005-2010 & 0.491 & 0.539 & 0.000 & 0.000 & 0.000 & 350,858 \\
\hline$N$ & & & & & & \\
\hline
\end{tabular}


Table 3. Descriptive characteristics of birth mothers, by parent type, child's gender, and birth cohort.

\begin{tabular}{|c|c|c|c|c|c|c|c|c|c|c|c|c|}
\hline & \multicolumn{4}{|c|}{ Lesbian parents } & \multicolumn{4}{|c|}{ Other parents } & \multicolumn{4}{|c|}{ Married opposite-sex parents } \\
\hline & \multicolumn{2}{|c|}{ Boys } & \multicolumn{2}{|c|}{ Girls } & \multicolumn{2}{|c|}{ Boys } & \multicolumn{2}{|c|}{ Girls } & \multicolumn{2}{|c|}{ Boys } & \multicolumn{2}{|c|}{ Girls } \\
\hline & $95-04$ & $05-10$ & $95-04$ & $05-10$ & $95-04$ & $05-10$ & $95-04$ & $05-10$ & $95-04$ & $05-10$ & $95-04$ & $05-10$ \\
\hline Mother's age at birth & 33.2 & 33.2 & 33.6 & 33.5 & 30.0 & 30.8 & 30.0 & 30.8 & 31.0 & 31.7 & 31.0 & 31.7 \\
\hline Teenage mother & 0 & 0.003 & 0 & 0 & 0.013 & 0.012 & 0.013 & 0.011 & 0.004 & 0.004 & 0.005 & 0.003 \\
\hline \multicolumn{13}{|l|}{ Child's birth quarter } \\
\hline 1st birth quarter & 0.242 & 0.222 & 0.211 & 0.226 & 0.254 & 0.248 & 0.253 & 0.250 & 0.257 & 0.249 & 0.256 & 0.252 \\
\hline 2nd birth quarter & 0.152 & 0.237 & 0.237 & 0.241 & 0.267 & 0.265 & 0.267 & 0.264 & 0.270 & 0.266 & 0.271 & 0.266 \\
\hline 3rd birth quarter & 0.273 & 0.281 & 0.263 & 0.267 & 0.256 & 0.261 & 0.259 & 0.261 & 0.252 & 0.257 & 0.255 & 0.258 \\
\hline 4th birth quarter & 0.333 & 0.260 & 0.289 & 0.267 & 0.222 & 0.226 & 0.221 & 0.226 & 0.221 & 0.227 & 0.219 & 0.225 \\
\hline \multicolumn{13}{|l|}{ Mother's level of schooling ${ }^{\text {a) }}$} \\
\hline Compulsory school $<9$ years & 0 & 0 & 0 & 0 & 0.020 & 0.026 & 0.020 & 0.027 & 0.033 & 0.041 & 0.033 & 0.042 \\
\hline Compulsory school 9 years & 0.030 & 0.048 & 0.079 & 0.020 & 0.072 & 0.076 & 0.072 & 0.076 & 0.058 & 0.058 & 0.059 & 0.058 \\
\hline High school $\leq 2$ years & 0.152 & 0.063 & 0.184 & 0.084 & 0.229 & 0.106 & 0.228 & 0.106 & 0.193 & 0.100 & 0.192 & 0.100 \\
\hline High school 3 years & 0.091 & 0.210 & 0.158 & 0.220 & 0.238 & 0.281 & 0.237 & 0.282 & 0.199 & 0.216 & 0.200 & 0.215 \\
\hline University degree $<3$ years & 0.182 & 0.117 & 0.316 & 0.183 & 0.158 & 0.124 & 0.158 & 0.125 & 0.171 & 0.128 & 0.170 & 0.131 \\
\hline University degree $\geq 3$ years & 0.545 & 0.563 & 0.263 & 0.493 & 0.279 & 0.374 & 0.280 & 0.372 & 0.338 & 0.437 & 0.339 & 0.434 \\
\hline Missing information & 0 & 0 & 0 & 0 & 0.005 & 0.013 & 0.005 & 0.013 & 0.007 & 0.020 & 0.008 & 0.020 \\
\hline Mother born abroad & 0.061 & 0.108 & 0.026 & 0.081 & 0.171 & 0.210 & 0.172 & 0.210 & 0.265 & 0.321 & 0.266 & 0.322 \\
\hline \multicolumn{13}{|l|}{ Mother's region of residence ${ }^{b}$ ) } \\
\hline Metropolitan county & 0.606 & 0.763 & 0.711 & 0.739 & 0.528 & 0.553 & 0.528 & 0.553 & 0.576 & 0.604 & 0.578 & 0.604 \\
\hline$N$ of older siblings ${ }^{\mathrm{c})}$ & 0.121 & 0.162 & 0.158 & 0.148 & 0.513 & 0.672 & 0.514 & 0.673 & 0.628 & 0.820 & 0.625 & 0.819 \\
\hline Multiple births & 0 & 0 & 0.053 & 0.006 & 0.030 & 0.027 & 0.031 & 0.028 & 0.033 & 0.029 & 0.034 & 0.029 \\
\hline
\end{tabular}

Notes: ${ }^{\text {a) }}$ The mother's educational attainment is the maximum level observed in 1992, 2000 or in $2010 .{ }^{\text {b) }}$ The mother's region of residence is observed in the child's birth year. ${ }^{\text {c) }}$ The number of sibling comprises siblings and half siblings born by the birth mother and adoptive siblings adopted by the birth mother. 
Table 4. Birth weight of children with lesbian, other and opposite-sex parents, by child birth cohort and gender.

\begin{tabular}{cccccc}
\multicolumn{3}{c}{ Sample 1 $^{\text {a) }}$} & \multicolumn{3}{c}{ Sample 2 $^{\text {b) }}$} \\
\hline Q10 & $\begin{array}{c}\text { Share low } \\
\text { birth } \\
\text { weight } \\
(<2500 \mathrm{~g})\end{array}$ & Q10 & Mean & $\begin{array}{c}\text { Share low } \\
\text { birth } \\
\text { weight } \\
(<2500 \mathrm{~g})\end{array}$ \\
\hline
\end{tabular}

\begin{tabular}{|c|c|c|c|c|c|c|}
\hline \multicolumn{7}{|l|}{ 1995-2004 } \\
\hline Lesbian parents, boys & 2,990 & 3,540 & 0 & 2,970 & 3,514 & 0 \\
\hline Lesbian parents, girls & 2,865 & 3,452 & 0.026 & 2,865 & 3,419 & 0.030 \\
\hline Other parents, boys & 2,895 & 3,596 & 0.040 & 2,905 & 3,601 & 0.038 \\
\hline Other parents, girls & 2,810 & 3,470 & 0.045 & 2,820 & 3,476 & 0.043 \\
\hline $\begin{array}{l}\text { Married opposite-sex } \\
\text { parents, boys }\end{array}$ & 2,900 & 3,602 & 0.039 & 2,910 & 3,607 & 0.037 \\
\hline $\begin{array}{l}\text { Married opposite-sex } \\
\text { parents, girls }\end{array}$ & 2,815 & 3,476 & 0.044 & 2,825 & 3,482 & 0.042 \\
\hline \multicolumn{7}{|l|}{ 2005-2010 } \\
\hline Lesbian parents, boys & 2,860 & 3,485 & 0.051 & 2,950 & 3,529 & 0.024 \\
\hline Lesbian parents, girls & 2,665 & 3,359 & 0.078 & 2,698 & 3,372 & 0.065 \\
\hline Other parents, boys & 2,890 & 3,573 & 0.040 & 2,895 & 3,578 & 0.038 \\
\hline Other parents, girls & 2,800 & 3,449 & 0.044 & 2,810 & 3,454 & 0.042 \\
\hline $\begin{array}{l}\text { Married opposite-sex } \\
\text { parents, boys }\end{array}$ & 2,895 & 3,575 & 0.038 & 2,900 & 3,579 & 0.037 \\
\hline $\begin{array}{l}\text { Married opposite-sex } \\
\text { parents, girls }\end{array}$ & 2,805 & 3,452 & 0.043 & 2,815 & 3,457 & 0.041 \\
\hline
\end{tabular}


Table 5. Descriptive characteristics for birth weight sample, by gender and child birth cohort.

\begin{tabular}{|c|c|c|c|c|c|c|c|c|c|c|c|c|}
\hline & \multicolumn{4}{|c|}{ Lesbian parents } & \multicolumn{4}{|c|}{ Other parents } & \multicolumn{4}{|c|}{ Married opposite-sex parents } \\
\hline & \multicolumn{2}{|c|}{ Boys } & \multicolumn{2}{|c|}{ Girls } & \multicolumn{2}{|c|}{ Boys } & \multicolumn{2}{|c|}{ Girls } & \multicolumn{2}{|c|}{ Boys } & \multicolumn{2}{|c|}{ Girls } \\
\hline & $95-04$ & $05-10$ & $95-04$ & $05-10$ & $95-04$ & $05-10$ & $95-04$ & $05-10$ & $95-04$ & $05-10$ & $95-04$ & $05-10$ \\
\hline Receipt of fertility treatment ${ }^{a)}$ & 0.107 & 0.306 & 0.182 & 0.271 & 0.035 & 0.049 & 0.035 & 0.049 & 0.046 & 0.063 & 0.046 & 0.063 \\
\hline $\begin{array}{l}\text { Birth mother's BMI at } \\
\text { registration at maternity clinic }\end{array}$ & 24.3 & 24.7 & 24.3 & 24.4 & 24.3 & 24.6 & 24.3 & 24.6 & 24.2 & 24.6 & 24.2 & 24.6 \\
\hline $\begin{array}{l}\text { Birth mother overweight }{ }^{\text {b) }} \text { at } \\
\text { registration at maternity clinic }\end{array}$ & 0.250 & 0.409 & 0.424 & 0.355 & 0.339 & 0.368 & 0.337 & 0.366 & 0.333 & 0.371 & 0.333 & 0.368 \\
\hline $\begin{array}{l}\text { Birth mother obese }{ }^{\mathrm{c})} \text { at } \\
\text { registration at maternity clinic }\end{array}$ & 0.107 & 0.117 & 0.061 & 0.097 & 0.097 & 0.119 & 0.096 & 0.117 & 0.093 & 0.119 & 0.093 & 0.117 \\
\hline $\begin{array}{l}\text { Birth mother smoker at } \\
\text { registration at maternity clinic }\end{array}$ & 0 & 0.021 & 0.091 & 0.023 & 0.125 & 0.071 & 0.124 & 0.071 & 0.080 & 0.046 & 0.079 & 0.045 \\
\hline $\begin{array}{l}\text { Birth mother heavy smoker }{ }^{d} \text { ) at } \\
\text { registration at maternity clinic }\end{array}$ & 0 & 0.003 & 0.030 & 0.010 & 0.040 & 0.017 & 0.040 & 0.016 & 0.025 & 0.011 & 0.026 & 0.010 \\
\hline
\end{tabular}

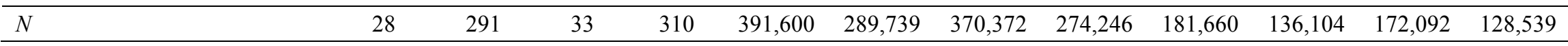

Notes:

a) Indicates receipt of any type of artificial fertility treatment.

b) Following WHO's definition, overweight is defined as having a BMI between 25.0 and 29.9.

c) Following WHO's definition, obesity is defined as having a BMI larger than or equal to 30.0.

d) The birth mother is a heavy smoker if she smokes ten or more cigarettes a day. 
Table 6. OLS estimates of $\log$ birth weight.

\begin{tabular}{|c|c|c|c|c|c|c|}
\hline & $(1)$ & $(2)$ & (3) & $(4)$ & $(5)$ & $(6)$ \\
\hline \multicolumn{7}{|l|}{ A. Comparison with other children } \\
\hline Lesbian parents $\mathrm{x}$ Boy & $\begin{array}{l}-0.023^{*} \\
(0.012)\end{array}$ & $\begin{array}{l}-0.029^{* *} \\
(0.012)\end{array}$ & $\begin{array}{l}-0.030^{* *} \\
(0.012)\end{array}$ & $\begin{array}{l}-0.029^{* *} \\
(0.012)\end{array}$ & $\begin{array}{l}-0.013 \\
(0.012)\end{array}$ & $\begin{array}{l}-0.026^{* *} \\
(0.012)\end{array}$ \\
\hline Lesbian parents x Girl & $\begin{array}{l}-0.025^{* *} \\
(0.011)\end{array}$ & $\begin{array}{l}-0.032^{* * *} \\
(0.011)\end{array}$ & $\begin{array}{c}-0.033^{* * *} \\
(0.011)\end{array}$ & $\begin{array}{l}-0.033^{* * *} \\
(0.011)\end{array}$ & $\begin{array}{l}-0.015 \\
(0.011)\end{array}$ & $\begin{array}{l}-0.026^{* *} \\
(0.011)\end{array}$ \\
\hline Girl & $\begin{array}{l}-0.035^{* * *} \\
(0.000)\end{array}$ & $\begin{array}{l}-0.035^{* * *} \\
(0.000)\end{array}$ & $\begin{array}{c}-0.035^{* * *} \\
(0.000)\end{array}$ & $\begin{array}{l}-0.035^{* * *} \\
(0.000)\end{array}$ & $\begin{array}{l}-0.035^{* * *} \\
(0.000)\end{array}$ & $\begin{array}{r}-0.034^{* * *} \\
(0.000)\end{array}$ \\
\hline $\begin{array}{l}\text { Prob > F: (Lesbian parents x Boy })= \\
(\text { Lesbian parents x Girl) }\end{array}$ & 0.901 & 0.837 & 0.821 & 0.822 & 0.877 & 0.977 \\
\hline $\begin{array}{l}\text { Prob }>\text { F: Lesbian parents } \times \text { Boy }=0 \\
\text { and Lesbian parents } x \text { Girl }=0\end{array}$ & 0.016 & 0.002 & 0.001 & 0.001 & 0.238 & 0.008 \\
\hline$N$ & & & $1,539,760$ & & & \\
\hline$R^{2}$ & 0.008 & 0.015 & 0.016 & 0.017 & 0.029 & 0.117 \\
\hline \multicolumn{7}{|c|}{ B. Comparison with children of married opposite-sex parents } \\
\hline Lesbian parents $\mathrm{x}$ Boy & $\begin{array}{l}-0.024^{*} \\
(0.012)\end{array}$ & $\begin{array}{l}-0.034^{* * *} \\
(0.012)\end{array}$ & $\begin{array}{l}-0.034^{* * *} \\
(0.012)\end{array}$ & $\begin{array}{l}-0.034^{* * *} \\
(0.012)\end{array}$ & $\begin{array}{l}-0.015 \\
(0.012)\end{array}$ & $\begin{array}{l}-0.030^{* *} \\
(0.012)\end{array}$ \\
\hline Lesbian parents x Girl & $\begin{array}{l}-0.026^{* *} \\
(0.011)\end{array}$ & $\begin{array}{c}-0.037^{* * *} \\
(0.011)\end{array}$ & $\begin{array}{l}-0.037^{* * *} \\
(0.011)\end{array}$ & $\begin{array}{l}-0.037^{* * *} \\
(0.011)\end{array}$ & $\begin{array}{l}-0.017 \\
(0.011)\end{array}$ & $\begin{array}{c}-0.029^{* * *} \\
(0.011)\end{array}$ \\
\hline Girl & $\begin{array}{c}-0.035^{* * *} \\
(0.000)\end{array}$ & $\begin{array}{l}-0.035^{* * *} \\
(0.000)\end{array}$ & $\begin{array}{l}-0.035^{* * *} \\
(0.000)\end{array}$ & $\begin{array}{l}-0.035^{* * *} \\
(0.000)\end{array}$ & $\begin{array}{c}-0.035^{* * *} \\
(0.000)\end{array}$ & $\begin{array}{c}-0.034^{* * *} \\
(0.000)\end{array}$ \\
\hline $\begin{array}{l}\text { Prob }>\text { F: }(\text { Lesbian parents } x \text { Boy })= \\
(\text { Lesbian parents x Girl })\end{array}$ & 0.902 & 0.834 & 0.811 & 0.812 & 0.867 & 0.994 \\
\hline $\begin{array}{l}\text { Prob }>\text { F: Lesbian parents } x \text { Boy }=0 \\
\text { and Lesbian parents } x \text { Girl }=0\end{array}$ & 0.012 & 0.000 & 0.000 & 0.000 & 0.165 & 0.002 \\
\hline$N$ & & & 722,770 & & & \\
\hline$R^{2}$ & 0.008 & 0.020 & 0.021 & 0.021 & 0.034 & 0.129 \\
\hline
\end{tabular}

\section{Note to Table 6:}

In column (1) control variables for the child's birth year are added. In column (2) control variables for the mother's education (7 levels), region of residence (county), and immigrant status are added. In column (3) control variables for the mother's age at the child's birth and an indicator for teenage mother are added. In column (4) control variables for the child's birth quarter are added. In column (5) a control variable for number of older siblings are added. In column (6) a control variable for multiple births is added. Standard errors, clustered at the biological mother, are shown in parentheses. ${ }^{*} p<0.10,{ }^{* *} p<0.05,{ }^{* * *} p<0.01$ 
Table 7. LPM estimates of the probability of having a low birth weight $(<2500 \mathrm{~g})$.

\begin{tabular}{|c|c|c|c|c|c|c|}
\hline & $(1)$ & $(2)$ & (3) & (4) & $(5)$ & $(6)$ \\
\hline \multicolumn{7}{|l|}{ A. Comparison with other children } \\
\hline Lesbian parents x Boy & $\begin{array}{c}0.007 \\
(0.013)\end{array}$ & $\begin{array}{c}0.009 \\
(0.013)\end{array}$ & $\begin{array}{c}0.008 \\
(0.013)\end{array}$ & $\begin{array}{c}0.008 \\
(0.013)\end{array}$ & $\begin{array}{l}-0.001 \\
(0.013)\end{array}$ & $\begin{array}{c}0.013 \\
(0.013)\end{array}$ \\
\hline Lesbian parents x Girl & $\begin{array}{l}0.029^{* *} \\
(0.014)\end{array}$ & $\begin{array}{l}0.031^{* *} \\
(0.014)\end{array}$ & $\begin{array}{l}0.030^{* *} \\
(0.014)\end{array}$ & $\begin{array}{l}0.030^{* *} \\
(0.014)\end{array}$ & $\begin{array}{c}0.020 \\
(0.014)\end{array}$ & $\begin{array}{l}0.031^{* *} \\
(0.014)\end{array}$ \\
\hline Girl & $\begin{array}{l}0.005^{* * *} \\
(0.000)\end{array}$ & $\begin{array}{l}0.005^{* * *} \\
(0.000)\end{array}$ & $\begin{array}{l}0.005^{\text {*** }} \\
(0.000)\end{array}$ & $\begin{array}{l}0.005^{* * *} \\
(0.000)\end{array}$ & $\begin{array}{l}0.005^{* * *} \\
(0.000)\end{array}$ & $\begin{array}{l}0.004^{\text {*** }} \\
(0.000)\end{array}$ \\
\hline $\begin{array}{l}\text { Prob > F: }(\text { Lesbian parents } \times \text { Boy })= \\
(\text { Lesbian parents } x \text { Girl })\end{array}$ & 0.255 & 0.254 & 0.259 & 0.259 & 0.272 & 0.341 \\
\hline $\begin{array}{l}\text { Prob }>\text { F: Lesbian parents } x \text { Boy }=0 \\
\text { and Lesbian parents } x \text { Girl }=0\end{array}$ & 0.126 & 0.078 & 0.104 & 0.107 & 0.378 & 0.053 \\
\hline$N$ & & & $1,539,760$ & & & \\
\hline Adjusted $R^{2}$ & 0.000 & 0.001 & 0.002 & 0.002 & 0.005 & 0.100 \\
\hline \multicolumn{7}{|c|}{ B. Comparison with children of married opposite-sex parents } \\
\hline Lesbian parents $\mathrm{x}$ Boy & $\begin{array}{c}0.008 \\
(0.013)\end{array}$ & $\begin{array}{c}0.011 \\
(0.013)\end{array}$ & $\begin{array}{c}0.010 \\
(0.013)\end{array}$ & $\begin{array}{c}0.010 \\
(0.013)\end{array}$ & $\begin{array}{c}-0.001 \\
(0.013)\end{array}$ & $\begin{array}{c}0.015 \\
(0.013)\end{array}$ \\
\hline Lesbian parents x Girl & $\begin{array}{l}0.030^{* *} \\
(0.014)\end{array}$ & $\begin{array}{l}0.033^{* *} \\
(0.014)\end{array}$ & $\begin{array}{l}0.032^{* *} \\
(0.014)\end{array}$ & $\begin{array}{l}0.032^{* *} \\
(0.014)\end{array}$ & $\begin{array}{c}0.020 \\
(0.014)\end{array}$ & $\begin{array}{l}0.033^{* *} \\
(0.014)\end{array}$ \\
\hline Girl & $\begin{array}{l}0.005^{\text {*** }} \\
(0.000)\end{array}$ & $\begin{array}{l}0.005^{\text {*** }} \\
(0.000)\end{array}$ & $\begin{array}{l}0.005^{* * *} \\
(0.000)\end{array}$ & $\begin{array}{l}0.005^{* * *} \\
(0.000)\end{array}$ & $\begin{array}{l}0.005^{* * *} \\
(0.000)\end{array}$ & $\begin{array}{l}0.005^{\text {** }} \\
(0.000)\end{array}$ \\
\hline $\begin{array}{l}\text { Prob }>\text { F: }(\text { Lesbian parents } \times \text { Boy })= \\
(\text { Lesbian parents } \times \text { Girl })\end{array}$ & 0.256 & 0.259 & 0.263 & 0.263 & 0.277 & 0.341 \\
\hline $\begin{array}{l}\text { Prob > F: Lesbian parents x Boy }=0 \\
\text { and Lesbian parents x Girl }=0\end{array}$ & 0.097 & 0.057 & 0.070 & 0.073 & 0.370 & 0.035 \\
\hline$N$ & & & 722,770 & & & \\
\hline Adjusted $R^{2}$ & 0.000 & 0.001 & 0.002 & 0.002 & 0.005 & 0.104 \\
\hline
\end{tabular}

\section{Note to Table 7:}

In column (1) control variables for the child's birth year are added. In column (2) control variables for the mother's education (7 levels), region of residence (county), and immigrant status are added. In column (3) control variables for the mother's age at the child's birth and an indicator for teenage mother are added. In column (4) control variables for the child's birth quarter are added. In column (5) a control variable for number of older siblings are added. In column (6) a control variable for multiple births is added. Standard errors, clustered at the biological mother, are shown in parentheses. ${ }^{*} p<0.10,^{* *} p<0.05,{ }^{* * *} p<0.01$ 
Table 8. OLS estimates of $\log$ birth weight.

\begin{tabular}{|c|c|c|c|c|c|c|c|c|c|}
\hline & $(1)$ & $(2)$ & $(3)$ & (4) & $(5)$ & $(6)$ & $(7)$ & $(8)$ & $(9)$ \\
\hline \multicolumn{10}{|l|}{ A. Comparison with other children } \\
\hline Lesbian parents $\mathrm{x}$ Boy & $\begin{array}{l}-0.010 \\
(0.009)\end{array}$ & $\begin{array}{l}-0.016^{*} \\
(0.009)\end{array}$ & $\begin{array}{l}-0.017^{*} \\
(0.009)\end{array}$ & $\begin{array}{l}-0.017^{*} \\
(0.009)\end{array}$ & $\begin{array}{c}0.001 \\
(0.009)\end{array}$ & $\begin{array}{c}-0.000 \\
(0.009)\end{array}$ & $\begin{array}{c}-0.001 \\
(0.009)\end{array}$ & $\begin{array}{c}0.011 \\
(0.009)\end{array}$ & $\begin{array}{c}-0.011 \\
(0.009)\end{array}$ \\
\hline Lesbian parents x Girl & $\begin{array}{l}-0.024^{* *} \\
(0.011)\end{array}$ & $\begin{array}{c}-0.032^{* * *} \\
(0.011)\end{array}$ & $\begin{array}{c}-0.033^{* * *} \\
(0.011)\end{array}$ & $\begin{array}{c}-0.033^{* * *} \\
(0.011)_{* * *}\end{array}$ & $\begin{array}{l}-0.017 \\
(0.011)_{* * *}\end{array}$ & $\begin{array}{l}-0.017 \\
(0.011)_{* * *}\end{array}$ & $\begin{array}{l}-0.017 \\
(0.011)_{* * *}\end{array}$ & $\begin{array}{l}-0.004 \\
(0.011)\end{array}$ & $\begin{array}{l}-0.021^{*} \\
(0.011)\end{array}$ \\
\hline Girl & $\begin{array}{c}-0.034^{* * *} \\
(0.000)\end{array}$ & $\begin{array}{c}-0.034^{* * *} \\
(0.000)\end{array}$ & $\begin{array}{c}-0.034^{* * *} \\
(0.000)\end{array}$ & $\begin{array}{c}-0.034^{* * *} \\
(0.000)\end{array}$ & $\begin{array}{c}-0.034^{* * *} \\
(0.000)\end{array}$ & $\begin{array}{c}-0.034^{\text {**** }} \\
(0.000)\end{array}$ & $\begin{array}{c}-0.034^{* * *} \\
(0.000)\end{array}$ & $\begin{array}{c}-0.034^{* * *} \\
(0.000)\end{array}$ & $\begin{array}{c}-0.034^{* * *} \\
(0.000)\end{array}$ \\
\hline $\begin{array}{l}\text { Prob }>\text { F: Lesbian parents } \times \text { Boy }=0 \\
\text { and Lesbian parents } x \text { Girl }=0\end{array}$ & 0.061 & 0.006 & 0.004 & 0.004 & 0.300 & 0.314 & 0.289 & 0.465 & 0.087 \\
\hline$N$ & & & & & $1,326,619$ & & & & \\
\hline$R^{2}$ & 0.008 & 0.015 & 0.017 & 0.017 & 0.023 & 0.036 & 0.043 & 0.053 & 0.136 \\
\hline \multicolumn{10}{|c|}{ B. Comparison with children of married opposite-sex parents } \\
\hline Lesbian parents $\mathrm{x}$ Boy & $\begin{array}{l}-0.011 \\
(0.009)\end{array}$ & $\begin{array}{l}-0.020^{* *} \\
(0.009)\end{array}$ & $\begin{array}{l}-0.021^{* *} \\
(0.009)\end{array}$ & $\begin{array}{l}-0.021^{* *} \\
(0.009)\end{array}$ & $\begin{array}{l}-0.003 \\
(0.009)\end{array}$ & $\begin{array}{l}-0.004 \\
(0.009)\end{array}$ & $\begin{array}{l}-0.004 \\
(0.009)\end{array}$ & $\begin{array}{c}0.009 \\
(0.009)\end{array}$ & $\begin{array}{l}-0.013 \\
(0.009)\end{array}$ \\
\hline Lesbian parents x Girl & $\begin{array}{l}-0.025^{* *} \\
(0.011)\end{array}$ & $\begin{array}{l}-0.037^{* * *} \\
(0.011)\end{array}$ & $\begin{array}{l}-0.037^{* * *} \\
(0.011)\end{array}$ & $\begin{array}{l}-0.037^{* * *} \\
(0.011)_{* * *}\end{array}$ & $\begin{array}{l}-0.022^{*} \\
(0.011)\end{array}$ & $\begin{array}{l}-0.021^{*} \\
(0.011)_{* *}^{*}\end{array}$ & $\begin{array}{l}-0.021^{*} \\
(0.011)_{* * *}\end{array}$ & $\begin{array}{l}-0.007 \\
(0.011)\end{array}$ & $\begin{array}{l}-0.024^{* *} \\
(0.011)\end{array}$ \\
\hline Girl & $\begin{array}{l}-0.034^{* * *} \\
(0.000)\end{array}$ & $\begin{array}{l}-0.034^{* * *} \\
(0.000)\end{array}$ & $\begin{array}{l}-0.034^{* * *} \\
(0.000)\end{array}$ & $\begin{array}{l}-0.034^{* * *} \\
(0.000)\end{array}$ & $\begin{array}{c}-0.034^{* * *} \\
(0.000)\end{array}$ & $\begin{array}{l}-0.034^{* * *} \\
(0.000)\end{array}$ & $\begin{array}{l}-0.034^{* * *} \\
(0.000)\end{array}$ & $\begin{array}{l}-0.034^{* * *} \\
(0.000)\end{array}$ & $\begin{array}{l}-0.034^{* * *} \\
(0.000)\end{array}$ \\
\hline $\begin{array}{l}\text { Prob }>\text { F: }(\text { Lesbian parents } x \text { Boy })= \\
(\text { Lesbian parents } x \text { Girl })\end{array}$ & 0.298 & 0.231 & 0.224 & 0.227 & 0.175 & 0.214 & 0.231 & 0.258 & 0.413 \\
\hline $\begin{array}{l}\text { Prob }>\text { F: Lesbian parents } x \text { Boy }=0 \\
\text { and Lesbian parents } x \text { Girl }=0\end{array}$ & 0.047 & 0.001 & 0.001 & 0.001 & 0.153 & 0.157 & 0.150 & 0.501 & 0.038 \\
\hline$N$ & & & & & 619,057 & & & & \\
\hline$R^{2}$ & 0.008 & 0.019 & 0.021 & 0.021 & 0.031 & 0.043 & & & \\
\hline
\end{tabular}

\section{Note to Table 8:}

In column (1) control variables for the child's birth year are added. In column (2) control variables for the mother's education (7 levels), region of residence (county), and immigrant status are added. In column (3) control variables for the mother's age at the child's birth and an indicator for teenage mother are added. In column (4) control variables for the child's birth quarter are added. In column (5) a control variable indicating receipt of any type of fertility treatment is added. In column (6) control variables for the mother's BMI and if the mother is overweight and obese at registration at the maternity clinic, respectively, are added. In column (7) control variables for the mother's smoking habits at the registration at the maternity clinic (smoker, heavy smoker) are added. In column (8) a control variable for number of older siblings are added. In column (9) a control variable for multiple births is added. Standard errors, clustered at the biological mother, are shown in parentheses. ${ }^{*} p<0.10,{ }^{* *} p<0.05,{ }^{* * *} p<0.01$ 
Table 9. LPM estimates of the probability of having a low birth weight $(<2500 \mathrm{~g})$.

\begin{tabular}{|c|c|c|c|c|c|c|c|c|c|}
\hline & $(1)$ & $(2)$ & (3) & $(4)$ & $(5)$ & $(6)$ & $(7)$ & $(8)$ & $(9)$ \\
\hline \multicolumn{10}{|l|}{ A. Comparison with other children } \\
\hline Lesbian parents $\mathrm{x}$ Boy & $\begin{array}{l}-0.016^{* *} \\
(0.008)\end{array}$ & $\begin{array}{l}-0.013 \\
(0.008)\end{array}$ & $\begin{array}{l}-0.015^{*} \\
(0.008)\end{array}$ & $\begin{array}{l}-0.015^{*} \\
(0.008)\end{array}$ & $\begin{array}{c}-0.031^{* * *} \\
(0.008)\end{array}$ & $\begin{array}{l}-0.031^{* * *} \\
(0.008)\end{array}$ & $\begin{array}{l}-0.030^{* * *} \\
(0.008)\end{array}$ & $\begin{array}{l}-0.036^{* * *} \\
(0.008)\end{array}$ & $\begin{array}{l}-0.014^{*} \\
(0.008)\end{array}$ \\
\hline Lesbian parents x Girl & $\begin{array}{c}0.019 \\
(0.014)\end{array}$ & $\begin{array}{c}0.022 \\
(0.014)\end{array}$ & $\begin{array}{c}0.020 \\
(0.014)\end{array}$ & $\begin{array}{c}0.020 \\
(0.014)\end{array}$ & $\begin{array}{c}0.006 \\
(0.014)\end{array}$ & $\begin{array}{c}0.006 \\
(0.014)\end{array}$ & $\begin{array}{c}0.006 \\
(0.014)\end{array}$ & $\begin{array}{l}-0.000 \\
(0.014)\end{array}$ & $\begin{array}{c}0.017 \\
(0.013)\end{array}$ \\
\hline Girl & $\begin{array}{l}0.004^{* * * *} \\
(0.000)\end{array}$ & $\begin{array}{l}0.004^{* * *} \\
(0.000)\end{array}$ & $\begin{array}{l}0.004^{* * * *} \\
(0.000)\end{array}$ & $\begin{array}{l}0.004^{* * *} \\
(0.000)\end{array}$ & $\begin{array}{l}0.004^{* * * *} \\
(0.000)\end{array}$ & $\begin{array}{l}0.004^{* * *} \\
(0.000)\end{array}$ & $\begin{array}{l}0.004^{* * *} \\
(0.000)\end{array}$ & $\begin{array}{l}0.004^{* * *} \\
(0.000)\end{array}$ & $\begin{array}{l}0.004^{* * *} \\
(0.000)\end{array}$ \\
\hline $\begin{array}{l}\text { Prob }>\text { F: Lesbian parents } \times \text { Boy }=0 \\
\text { and Lesbian parents x Girl }=0\end{array}$ & 0.050 & 0.069 & 0.060 & 0.060 & 0.001 & 0.001 & 0.001 & 0.000 & 0.094 \\
\hline$N$ & & & & & $1,326,619$ & & & & \\
\hline Adjusted $R^{2}$ & 0.000 & 0.001 & 0.001 & 0.002 & 0.007 & 0.007 & 0.009 & 0.011 & 0.100 \\
\hline \multicolumn{10}{|c|}{ B. Comparison with children of married opposite-sex parents } \\
\hline Lesbian parents x Boy & $\begin{array}{l}-0.015^{*} \\
(0.008)\end{array}$ & $\begin{array}{l}-0.012 \\
(0.008)\end{array}$ & $\begin{array}{l}-0.013 \\
(0.008)\end{array}$ & $\begin{array}{l}-0.013 \\
(0.008)\end{array}$ & $\begin{array}{l}-0.029^{* * *} \\
(0.008)\end{array}$ & $\begin{array}{l}-0.029^{* * *} \\
(0.008)\end{array}$ & $\begin{array}{l}-0.028^{* * *} \\
(0.008)\end{array}$ & $\begin{array}{l}-0.035^{* * *} \\
(0.008)\end{array}$ & $\begin{array}{l}-0.013 \\
(0.008)\end{array}$ \\
\hline Lesbian parents x Girl & $\begin{array}{c}0.020 \\
(0.014)\end{array}$ & $\begin{array}{l}0.023^{*} \\
(0.014)\end{array}$ & $\begin{array}{c}0.022 \\
(0.014)\end{array}$ & $\begin{array}{c}0.022 \\
(0.014)\end{array}$ & $\begin{array}{c}0.008 \\
(0.014)\end{array}$ & $\begin{array}{c}0.008 \\
(0.014)\end{array}$ & $\begin{array}{c}0.008 \\
(0.014)\end{array}$ & $\begin{array}{c}0.001 \\
(0.014)\end{array}$ & $\begin{array}{c}0.019 \\
(0.014)\end{array}$ \\
\hline Girl & $\begin{array}{l}0.004^{* * *} \\
(0.001)\end{array}$ & $\begin{array}{l}0.004^{* * *} \\
(0.001)\end{array}$ & $\begin{array}{l}0.004^{* * *} \\
(0.001)\end{array}$ & $\begin{array}{l}0.004^{* * *} \\
(0.001)\end{array}$ & $\begin{array}{l}0.004^{* * * *} \\
(0.001)\end{array}$ & $\begin{array}{l}0.004^{* * *} \\
(0.001)\end{array}$ & $\begin{array}{l}0.004^{* * *} \\
(0.001)\end{array}$ & $\begin{array}{l}0.004^{* * *} \\
(0.001)\end{array}$ & $\begin{array}{l}0.004^{* * *} \\
(0.000)\end{array}$ \\
\hline $\begin{array}{l}\text { Prob }>\text { F: }(\text { Lesbian parents x Boy })= \\
(\text { Lesbian parents x Girl) }\end{array}$ & 0.027 & 0.027 & 0.028 & 0.028 & 0.020 & 0.021 & & & \\
\hline $\begin{array}{l}\text { Prob }>\text { F: Lesbian parents } x \text { Boy }=0 \\
\text { and Lesbian parents } x \text { Girl }=0\end{array}$ & 0.060 & 0.079 & 0.074 & 0.074 & 0.002 & 0.002 & & & \\
\hline$N$ & & & & & 619,057 & & & & \\
\hline Adjusted $R^{2}$ & 0.000 & 0.001 & 0.001 & 0.001 & 0.009 & 0.009 & 0.011 & 0.013 & 0.103 \\
\hline
\end{tabular}

\section{Note to Table 9:}

In column (1) control variables for the child's birth year are added. In column (2) control variables for the mother's education (7 levels), region of residence (county), and immigrant status are added. In column (3) control variables for the mother's age at the child's birth and an indicator for teenage mother are added. In column (4) control variables for the child's birth quarter are added. In column (5) a control variable indicating receipt of any type of fertility treatment is added. In column (6) control variables for the mother's BMI and if the mother is overweight and obese at registration at the maternity clinic, respectively, are added. In column (7) control variables for the mother's smoking habits at the registration at the maternity clinic (smoker, heavy smoker) are added. In column (8) a control variable for number of older siblings are added. In column (9) a control variable for multiple births is added. Standard errors, clustered at the biological mother, are shown in parentheses. ${ }^{*} p<0.10,{ }^{* *} p<0.05,{ }^{* * *} p<0.01$ 
Table 10. Share of hospitalizations due to diseases of the respiratory system up until the age of 10, by birth cohort and child gender.

\begin{tabular}{|c|c|c|c|c|c|c|}
\hline & \multicolumn{2}{|c|}{ Lesbian parents } & \multicolumn{2}{|c|}{ Other parents } & \multicolumn{2}{|c|}{$\begin{array}{l}\text { Married opposite-sex } \\
\text { parents }\end{array}$} \\
\hline & Boys & Girls & Boys & Girls & Boys & Girls \\
\hline \multicolumn{7}{|l|}{ Born 1995-2004 } \\
\hline $\begin{array}{l}\text { Diseases of the respiratory } \\
\text { system }^{\text {a) }}\end{array}$ & 0.061 & 0.079 & 0.109 & 0.078 & 0.105 & 0.076 \\
\hline $\begin{array}{l}\text { Avoidable diseases of the } \\
\text { respiratory system }{ }^{\text {b) }}\end{array}$ & 0 & 0 & 0.042 & 0.028 & 0.041 & 0.027 \\
\hline$N$ older siblings ${ }^{c)}$ & 0.121 & 0.211 & 0.513 & 0.515 & 0.627 & 0.626 \\
\hline$N$ younger siblings at age 4 & 0.182 & 0.105 & 0.371 & 0.366 & 0.356 & 0.355 \\
\hline \multicolumn{7}{|l|}{ Born 2005-2010 } \\
\hline $\begin{array}{l}\text { Diseases of the respiratory } \\
\text { system }\end{array}$ & 0.069 & 0.099 & 0.103 & 0.075 & 0.103 & 0.075 \\
\hline $\begin{array}{l}\text { Avoidable diseases of the } \\
\text { respiratory system }\end{array}$ & 0.039 & 0.038 & 0.042 & 0.028 & 0.041 & 0.028 \\
\hline$N$ older siblings & 0.162 & 0.151 & 0.672 & 0.673 & 0.820 & 0.819 \\
\hline$N$ younger siblings at age 4 & 0.078 & 0.113 & 0.224 & 0.221 & 0.212 & 0.212 \\
\hline
\end{tabular}

\section{Note:}

a) Diseases of the respiratory system are defined using the International Statistical Classification of Diseases and Related Health Problems ICD10. A child is classified as have been hospitalized due to diseases of the respiratory system if the child has been diagnosed according to any of the ICD codes J00-J99.

b) Avoidable hospitalizations refer to conditions for which hospitalization should be able to be avoided, either because the disease or condition could have been prevented from occurring or if the individual had had access to timely and effective primary care (see Page et al. 2007). Avoidable diseases of the respiratory system are defined using the International Statistical Classification of Diseases and Related Health Problems ICD10. A child is classified as have been hospitalized due to avoidable diseases of the respiratory system if the child has been diagnosed according to any of the ICD codes J02-J03, J06 and/or J43-J47.

c) The number of sibling comprises siblings and half siblings born by the birth mother and adoptive siblings adopted by the birth mother. 
Table 11. LPM estimates of the probability of hospitalization due to diseases of the respiratory system up until the age of 10.

\begin{tabular}{|c|c|c|c|c|c|c|c|}
\hline & $(1)$ & $(2)$ & (3) & $(4)$ & $(5)$ & $(6)$ & $(7)$ \\
\hline \multicolumn{8}{|l|}{ A. Comparison with other children } \\
\hline Lesbian parents $\mathrm{x}$ Boy & $\begin{array}{c}-0.034^{* * *} \\
(0.013)\end{array}$ & $\begin{array}{l}-0.025^{*} \\
(0.013)\end{array}$ & $\begin{array}{l}-0.024^{*} \\
(0.013)\end{array}$ & $\begin{array}{l}-0.024^{*} \\
(0.013)\end{array}$ & $\begin{array}{l}-0.020 \\
(0.013)\end{array}$ & $\begin{array}{l}-0.019 \\
(0.013)\end{array}$ & $\begin{array}{l}-0.021 \\
(0.013)\end{array}$ \\
\hline Lesbian parents x Girl & $\begin{array}{c}0.024 \\
(0.015)\end{array}$ & $\begin{array}{l}0.030^{*} \\
(0.015)\end{array}$ & $\begin{array}{l}0.031^{* * *} \\
(0.015)\end{array}$ & $\begin{array}{l}0.031^{* * *} \\
(0.015)\end{array}$ & $\begin{array}{l}0.035^{* *} \\
(0.015)\end{array}$ & $\begin{array}{l}0.037^{* *} \\
(0.015)\end{array}$ & $\begin{array}{l}0.034^{* *} \\
(0.015)\end{array}$ \\
\hline Girl & $\begin{array}{c}-0.029^{* * *} \\
(0.000)\end{array}$ & $\begin{array}{c}-0.029^{* * *} \\
(0.000)\end{array}$ & $\begin{array}{c}-0.029^{* * *} \\
(0.000)\end{array}$ & $\begin{array}{c}-0.029^{* * *} \\
(0.000)\end{array}$ & $\begin{array}{c}-0.030^{* * *} \\
(0.000)\end{array}$ & $\begin{array}{c}-0.030^{* * * *} \\
(0.000)\end{array}$ & $\begin{array}{c}-0.031^{* * *} \\
(0.000)\end{array}$ \\
\hline $\begin{array}{l}\text { Prob > F: }(\text { Lesbian parents x Boy })= \\
\text { (Lesbian parents x Girl) }\end{array}$ & 0.003 & 0.005 & 0.005 & 0.005 & 0.005 & 0.005 & 0.005 \\
\hline $\begin{array}{l}\text { Prob > F: Lesbian parents } x \text { Boy }=0 \\
\text { and Lesbian parents x Girl }=0\end{array}$ & 0.008 & 0.020 & 0.019 & 0.019 & 0.017 & 0.017 & 0.020 \\
\hline$N$ & & & & $1,539,760$ & & & \\
\hline Adjusted $R^{2}$ & 0.004 & 0.008 & 0.008 & 0.009 & 0.009 & 0.010 & 0.012 \\
\hline \multicolumn{8}{|c|}{ B. Comparison with children of married opposite-sex parents } \\
\hline Lesbian parents x Boy & $\begin{array}{c}-0.034^{* * *} \\
(0.013)\end{array}$ & $\begin{array}{c}-0.027^{* *} \\
(0.013)\end{array}$ & $\begin{array}{c}-0.026^{* *} \\
(0.013)\end{array}$ & $\begin{array}{c}-0.027^{* *} \\
(0.013)\end{array}$ & $\begin{array}{l}-0.023^{*} \\
(0.013)\end{array}$ & $\begin{array}{l}-0.021 \\
(0.013)\end{array}$ & $\begin{array}{l}-0.023^{*} \\
(0.013)\end{array}$ \\
\hline Lesbian parents x Girl & $\begin{array}{c}0.024 \\
(0.015)\end{array}$ & $\begin{array}{l}0.027^{*} \\
(0.015)\end{array}$ & $\begin{array}{l}0.028^{*} \\
(0.015)\end{array}$ & $\begin{array}{l}0.028^{*} \\
(0.015)\end{array}$ & $\begin{array}{l}0.033^{* *} \\
(0.015)\end{array}$ & $\begin{array}{l}0.034^{* *} \\
(0.015)\end{array}$ & $\begin{array}{l}0.031^{* *} \\
(0.015)\end{array}$ \\
\hline Girl & $\begin{array}{c}-0.029^{* * *} \\
(0.001)\end{array}$ & $\begin{array}{c}-0.029^{* * *} \\
(0.001)\end{array}$ & $\begin{array}{c}-0.029^{* * *} \\
(0.001)\end{array}$ & $\begin{array}{c}-0.029^{* * *} \\
(0.001)\end{array}$ & $\begin{array}{c}-0.029^{* * *} \\
(0.001)\end{array}$ & $\begin{array}{c}-0.029^{* * *} \\
(0.001)\end{array}$ & $\begin{array}{c}-0.031^{* * *} \\
(0.001)\end{array}$ \\
\hline $\begin{array}{l}\text { Prob > F: }(\text { Lesbian parents } x \text { Boy })= \\
(\text { Lesbian parents x Girl) }\end{array}$ & 0.003 & 0.006 & 0.005 & 0.005 & 0.005 & 0.005 & 0.006 \\
\hline $\begin{array}{l}\text { Prob > F: Lesbian parents } \mathrm{x} \text { Boy }=0 \\
\text { and Lesbian parents x Girl }=0\end{array}$ & 0.009 & 0.020 & 0.019 & 0.019 & 0.019 & 0.019 & 0.022 \\
\hline$N$ & & & & 722,770 & & & \\
\hline Adjusted $R^{2}$ & 0.004 & 0.008 & 0.008 & 0.009 & 0.009 & 0.010 & 0.012 \\
\hline
\end{tabular}

Note: In column (1) controls for the child's birth year are added. In column (2) control variables for the mother's education (7 levels), region of residence (county), immigrant status, and an indicator for whether the birth mother has moved between counties during the period of observation are added. In column ( 3 ) control variables for the mother's age at the child's birth and an indicator for teenage mother are added. In column (4) controls for the child's birth quarter are added. In column (5) control variables for the number of older siblings and the number of younger siblings at age 4 are added. In column (6) a control variable for multiple births is added. In column (7) control variables for birth weight and having a low birth weight $(<2500 \mathrm{~g})$ are added. Robust standard errors, clustered at the biological mother, are shown in parentheses. ${ }^{*} p<0.10,{ }^{* *} p<$ $0.05,{ }^{* * *} p<0.01$ 
Table 12. LPM estimates of the probability of hospitalization due to avoidable diseases of the respiratory system up until the age of 10.

\begin{tabular}{|c|c|c|c|c|c|c|c|}
\hline & (1) & (2) & (3) & (4) & $(5)$ & $(6)$ & (7) \\
\hline \multicolumn{8}{|l|}{ A. Comparison with other children } \\
\hline Lesbian parents $\mathrm{x}$ Boy & $\begin{array}{l}-0.006 \\
(0.010)\end{array}$ & $\begin{array}{l}-0.002 \\
(0.010)\end{array}$ & $\begin{array}{l}-0.002 \\
(0.010)\end{array}$ & $\begin{array}{l}-0.002 \\
(0.010)\end{array}$ & $\begin{array}{l}-0.001 \\
(0.010)\end{array}$ & $\begin{array}{l}-0.000 \\
(0.010)\end{array}$ & $\begin{array}{l}-0.001 \\
(0.010)\end{array}$ \\
\hline Lesbian parents x Girl & $\begin{array}{c}0.006 \\
(0.009)\end{array}$ & $\begin{array}{c}0.009 \\
(0.009)\end{array}$ & $\begin{array}{c}0.009 \\
(0.009)\end{array}$ & $\begin{array}{c}0.009 \\
(0.009)\end{array}$ & $\begin{array}{c}0.011 \\
(0.009)\end{array}$ & $\begin{array}{c}0.011 \\
(0.009)\end{array}$ & $\begin{array}{c}0.010 \\
(0.009)\end{array}$ \\
\hline Girl & $\begin{array}{l}-0.013^{* * *} \\
(0.000)\end{array}$ & $\begin{array}{l}-0.014^{* * *} \\
(0.000)\end{array}$ & $\begin{array}{c}-0.014^{* * *} \\
(0.000)\end{array}$ & $\begin{array}{l}-0.013^{* * *} \\
(0.000)\end{array}$ & $\begin{array}{l}-0.014^{* * * *} \\
(0.000)\end{array}$ & $\begin{array}{c}-0.014^{* * *} \\
(0.000)\end{array}$ & $\begin{array}{l}-0.015^{* * *} \\
(0.000)\end{array}$ \\
\hline $\begin{array}{l}\text { Prob > F: }(\text { Lesbian parents x Boy })= \\
\text { (Lesbian parents x Girl) }\end{array}$ & 0.373 & 0.405 & 0.398 & 0.399 & 0.390 & 0.397 & 0.412 \\
\hline $\begin{array}{l}\text { Prob > F: Lesbian parents } x \text { Boy }=0 \\
\text { and Lesbian parents x Girl }=0\end{array}$ & 0.672 & 0.624 & 0.588 & 0.601 & 0.515 & 0.483 & 0.572 \\
\hline$N$ & & & & $1,539,760$ & & & \\
\hline Adjusted $R^{2}$ & 0.002 & 0.004 & 0.004 & 0.004 & 0.004 & 0.005 & 0.006 \\
\hline \multicolumn{8}{|c|}{ B. Comparison with children of married opposite-sex parents } \\
\hline Lesbian parents $\mathrm{x}$ Boy & $\begin{array}{l}-0.005 \\
(0.010)\end{array}$ & $\begin{array}{l}-0.003 \\
(0.010)\end{array}$ & $\begin{array}{l}-0.003 \\
(0.010)\end{array}$ & $\begin{array}{l}-0.003 \\
(0.010)\end{array}$ & $\begin{array}{l}-0.001 \\
(0.010)\end{array}$ & $\begin{array}{l}-0.000 \\
(0.010)\end{array}$ & $\begin{array}{l}-0.002 \\
(0.010)\end{array}$ \\
\hline Lesbian parents x Girl & $\begin{array}{c}0.006 \\
(0.009)\end{array}$ & $\begin{array}{c}0.008 \\
(0.009)\end{array}$ & $\begin{array}{c}0.009 \\
(0.009)\end{array}$ & $\begin{array}{c}0.008 \\
(0.009)\end{array}$ & $\begin{array}{c}0.010 \\
(0.009)\end{array}$ & $\begin{array}{c}0.011 \\
(0.009)\end{array}$ & $\begin{array}{c}0.009 \\
(0.009)\end{array}$ \\
\hline Girl & $\begin{array}{l}-0.013^{* * *} \\
(0.000)\end{array}$ & $\begin{array}{l}-0.013^{* * *} \\
(0.000)\end{array}$ & $\begin{array}{l}-0.013^{* * *} \\
(0.000)\end{array}$ & $\begin{array}{l}-0.013^{* * *} \\
(0.000)\end{array}$ & $\begin{array}{l}-0.013^{* * *} \\
(0.000)\end{array}$ & $\begin{array}{c}-0.013^{* * *} \\
(0.000)\end{array}$ & $\begin{array}{c}-0.015^{* * *} \\
(0.000)\end{array}$ \\
\hline $\begin{array}{l}\text { Prob > F: }(\text { Lesbian parents x Boy })= \\
(\text { Lesbian parents x Girl })\end{array}$ & 0.378 & 0.412 & 0.406 & 0.407 & 0.400 & 0.405 & 0.420 \\
\hline $\begin{array}{l}\text { Prob }>\text { F: Lesbian parents } x \text { Boy }=0 \\
\text { and Lesbian parents x Girl }=0\end{array}$ & 0.673 & 0.645 & 0.629 & 0.640 & 0.549 & 0.516 & 0.611 \\
\hline$N$ & & & & 722,770 & & & \\
\hline Adjusted $R^{2}$ & 0.002 & 0.004 & 0.004 & 0.004 & 0.004 & 0.004 & 0.006 \\
\hline
\end{tabular}

Note: In column (1) controls for the child's birth year are added. In column (2) control variables for the mother's education (7 levels), region of residence (county), immigrant status, and an indicator for whether the birth mother has moved between counties during the period of observation are added. In column (3) control variables for the mother's age at the child's birth and an indicator for teenage mother are added. In column (4) controls for the child's birth quarter are added. In column (5) control variables for the number of older siblings and the number of younger siblings at age 4 are added. In column (6) a control variable for multiple births is added. In column (7) control variables for birth weight and having a low birth weight $(<2500 \mathrm{~g})$ are added. Robust standard errors, clustered at the biological mother, are shown in parentheses. ${ }^{*} p<0.10,{ }^{* *} p<$ $0.05,{ }^{* * *} p<0.01$ 
Table 13. School outcomes and descriptive statistics of children born in 2000-2004

\begin{tabular}{|c|c|c|c|c|c|c|}
\hline & \multicolumn{2}{|c|}{ Lesbian parents } & \multicolumn{2}{|c|}{ Other parents } & \multicolumn{2}{|c|}{$\begin{array}{l}\text { Married opposite-sex } \\
\text { parents }\end{array}$} \\
\hline & Boys & Girls & Boys & Girls & Boys & Girls \\
\hline Pass Math $^{\text {a) }}$ & 0.846 & 0.700 & 0.732 & 0.730 & 0.743 & 0.737 \\
\hline Pass Swedish ${ }^{\text {b) }}$ & 0.769 & 0.867 & 0.715 & 0.839 & 0.728 & 0.841 \\
\hline Percentile rank Math ${ }^{\mathrm{c})}$ & 58.7 & 50.6 & 49.9 & 50.1 & 51.0 & 50.9 \\
\hline Percentile rank Swedish ${ }^{\mathrm{d})}$ & 58.1 & 60.9 & 47.2 & 52.9 & 48.1 & 53.5 \\
\hline $\begin{array}{l}\text { Number of older siblings at age } \\
10^{\mathrm{e})}\end{array}$ & 0.077 & 0.133 & 0.570 & 0.577 & 0.709 & 0.713 \\
\hline $\begin{array}{l}\text { Number of younger siblings at } \\
\text { age } 10\end{array}$ & 0.269 & 0.300 & 0.537 & 0.525 & 0.489 & 0.485 \\
\hline Multiple births & 0 & 0.067 & 0.029 & 0.030 & 0.032 & 0.034 \\
\hline Birth weight (grams) & 3,457 & 3,470 & 3,614 & 3,485 & 3,619 & 3,490 \\
\hline Low birth weight $(<2500 \mathrm{~g})$ & 0 & 0.033 & 0.036 & 0.042 & 0.035 & 0.039 \\
\hline \multicolumn{7}{|l|}{ Hospitalization due to: } \\
\hline $\begin{array}{l}\text { Diseases of the respiratory } \\
\text { system }\end{array}$ & 0.077 & 0.100 & 0.107 & 0.077 & 0.106 & 0.075 \\
\hline $\begin{array}{l}\text { Avoidable diseases of the } \\
\text { respiratory system }\end{array}$ & 0 & 0 & 0.041 & 0.028 & 0.041 & 0.027 \\
\hline$N$ & 26 & 30 & 214,211 & 205,335 & 97,222 & 92,682 \\
\hline
\end{tabular}

a) The share of children who have attained the required level on all of the subtests B-F, zero otherwise. Subset A is not included since it is a group assignment. Subset G is not included since its content has changed over the time period studied.

b) The share of children who have attained the required level on all of the subtests B-H, zero otherwise. Subset A is not included since it is a group assignment.

c) The average percentile rank calculated using the test scores on subtests B-F.

d) The average percentile rank calculated using the test scores on subtests B and C. In the Swedish test, test scores are only available for subtests B and C.

e) The number of sibling comprises siblings and half siblings born by the birth mother and adoptive siblings adopted by the birth mother. 
Table 14. LPM estimates of the probability of getting a pass the national tests in Math taken in 3rd grade.

\begin{tabular}{|c|c|c|c|c|c|c|c|c|}
\hline & (1) & $(2)$ & (3) & (4) & $(5)$ & (6) & (7) & $(8)$ \\
\hline \multicolumn{9}{|l|}{ A. Comparison with other children } \\
\hline Lesbian parents x Boy & $\begin{array}{l}0.130^{*} \\
(0.070)\end{array}$ & $\begin{array}{c}0.077 \\
(0.075)\end{array}$ & $\begin{array}{c}0.076 \\
(0.074)\end{array}$ & $\begin{array}{c}0.082 \\
(0.072)\end{array}$ & $\begin{array}{c}0.077 \\
(0.072)\end{array}$ & $\begin{array}{c}0.075 \\
(0.072)\end{array}$ & $\begin{array}{c}0.079 \\
(0.072)\end{array}$ & $\begin{array}{c}0.079 \\
(0.072)\end{array}$ \\
\hline Lesbian parents x Girl & $\begin{array}{l}-0.010 \\
(0.082)\end{array}$ & $\begin{array}{l}-0.036 \\
(0.084)\end{array}$ & $\begin{array}{l}-0.035 \\
(0.085)\end{array}$ & $\begin{array}{c}-0.031 \\
(0.086)\end{array}$ & $\begin{array}{c}-0.037 \\
(0.086)\end{array}$ & $\begin{array}{c}-0.036 \\
(0.086)\end{array}$ & $\begin{array}{l}-0.038 \\
(0.085)\end{array}$ & $\begin{array}{l}-0.038 \\
(0.085)\end{array}$ \\
\hline Girl & $\begin{array}{l}-0.002 \\
(0.001)\end{array}$ & $\begin{array}{l}-0.001 \\
(0.001)\end{array}$ & $\begin{array}{l}-0.001 \\
(0.001)\end{array}$ & $\begin{array}{l}-0.001 \\
(0.001)\end{array}$ & $\begin{array}{l}-0.000 \\
(0.001)\end{array}$ & $\begin{array}{l}-0.000 \\
(0.001)\end{array}$ & $\begin{array}{l}0.003^{* *} \\
(0.001)\end{array}$ & $\begin{array}{l}0.003^{* * *} \\
(0.001)\end{array}$ \\
\hline $\begin{array}{l}\text { Prob > F: }(\text { Lesbian parents x Boy })= \\
(\text { Lesbian parents x Girl })\end{array}$ & 0.1936 & 0.3165 & 0.3260 & 0.3123 & 0.3100 & 0.3185 & 0.2914 & 0.2950 \\
\hline $\begin{array}{l}\text { Prob }>\text { F: Lesbian parents } x \text { Boy }= \\
0 \text { and Lesbian parents } x \text { Girl }=0\end{array}$ & 0.1797 & 0.5370 & 0.5457 & 0.4930 & 0.5152 & 0.5309 & 0.4922 & 0.4967 \\
\hline$N$ & & & & & 419,602 & & & \\
\hline Adjusted $R^{2}$ & 0.008 & 0.045 & 0.047 & 0.050 & 0.052 & 0.052 & 0.054 & 0.054 \\
\hline \multicolumn{9}{|c|}{ B. Comparison with children of married opposite-sex parents } \\
\hline Lesbian parents x Boy & $\begin{array}{l}0.118^{*} \\
(0.070)\end{array}$ & $\begin{array}{c}0.068 \\
(0.075)\end{array}$ & $\begin{array}{c}0.069 \\
(0.074)\end{array}$ & $\begin{array}{c}0.076 \\
(0.072)\end{array}$ & $\begin{array}{c}0.067 \\
(0.072)\end{array}$ & $\begin{array}{c}0.065 \\
(0.072)\end{array}$ & $\begin{array}{c}0.069 \\
(0.072)\end{array}$ & $\begin{array}{c}0.068 \\
(0.072)\end{array}$ \\
\hline Lesbian parents x Girl & $\begin{array}{l}-0.018 \\
(0.082)\end{array}$ & $\begin{array}{l}-0.042 \\
(0.085)\end{array}$ & $\begin{array}{l}-0.037 \\
(0.085)\end{array}$ & $\begin{array}{c}-0.033 \\
(0.086)\end{array}$ & $\begin{array}{l}-0.042 \\
(0.086)\end{array}$ & $\begin{array}{c}-0.042 \\
(0.086)\end{array}$ & $\begin{array}{c}-0.044 \\
(0.085)\end{array}$ & $\begin{array}{l}-0.043 \\
(0.085)\end{array}$ \\
\hline Girl & $\begin{array}{c}-0.006^{* * *} \\
(0.002)\end{array}$ & $\begin{array}{c}-0.005^{* * *} \\
(0.002)\end{array}$ & $\begin{array}{c}-0.005^{* * *} \\
(0.002)\end{array}$ & $\begin{array}{c}-0.005^{* *} \\
(0.002)\end{array}$ & $\begin{array}{l}-0.005^{* *} \\
(0.002)\end{array}$ & $\begin{array}{l}-0.005^{* *} \\
(0.002)\end{array}$ & $\begin{array}{l}-0.001 \\
(0.002)\end{array}$ & $\begin{array}{l}-0.002 \\
(0.002)\end{array}$ \\
\hline $\begin{array}{l}\text { Prob > F: }(\text { Lesbian parents x Boy })= \\
(\text { Lesbian parents x Girl })\end{array}$ & 0.2057 & 0.3328 & 0.3486 & 0.3331 & 0.3319 & 0.3415 & 0.3124 & 0.3166 \\
\hline $\begin{array}{l}\text { Prob }>\text { F: Lesbian parents } x \text { Boy }= \\
0 \text { and Lesbian parents x Girl }=0\end{array}$ & 0.2362 & 0.5871 & 0.5893 & 0.5378 & 0.5778 & 0.5954 & 0.5529 & 0.5582 \\
\hline$N$ & & & & 189,960 & & & & \\
\hline Adjusted $R^{2}$ & 0.008 & 0.056 & 0.058 & 0.061 & 0.062 & 0.062 & 0.064 & 0.064 \\
\hline
\end{tabular}

Note: In column (1) control variables for the child's birth year are added. In column (2) control variables for the mother's education ( 7 levels), region of residence (county), and immigrant status are added. In column (3) control variables for the mother's age at the child's birth and an indicator for teenage mother are added. In column (4) controls for the child's birth quarter are added. In column (5) control variables for the number of older siblings and the number of younger siblings at age 10 are added. In column (6) a control variable for multiple births is added. In column (7) control variables for birth weight and having a low birth weight $(<2500 \mathrm{~g})$ are added. In column $(8)$ control

variables for hospitalization due to (all types and avoidable) diseases of the respiratory system are added. Robust standard errors, clustered at the biological mother, are shown

in parentheses. ${ }^{*} p<0.10,{ }^{* *} p<0.05,{ }^{* * *} p<0.01$ 
Table 15. LPM estimates of the probability of getting a pass the national tests in Swedish taken in 3rd grade.

\begin{tabular}{|c|c|c|c|c|c|c|c|c|}
\hline & $(1)$ & $(2)$ & (3) & (4) & $(5)$ & (6) & $(7)$ & $(8)$ \\
\hline \multicolumn{9}{|l|}{ A. Comparison with other children } \\
\hline Lesbian parents $\mathrm{x}$ Boy & $\begin{array}{c}0.058 \\
(0.083)\end{array}$ & $\begin{array}{c}0.010 \\
(0.089)\end{array}$ & $\begin{array}{c}0.008 \\
(0.088)\end{array}$ & $\begin{array}{c}0.014 \\
(0.089)\end{array}$ & $\begin{array}{c}0.003 \\
(0.089)\end{array}$ & $\begin{array}{c}0.002 \\
(0.089)\end{array}$ & $\begin{array}{c}0.004 \\
(0.088)\end{array}$ & $\begin{array}{c}0.004 \\
(0.088)\end{array}$ \\
\hline Lesbian parents x Girl & $\begin{array}{c}0.027 \\
(0.061)\end{array}$ & $\begin{array}{c}0.005 \\
(0.064)\end{array}$ & $\begin{array}{c}0.004 \\
(0.065)\end{array}$ & $\begin{array}{c}0.008 \\
(0.066)\end{array}$ & $\begin{array}{l}-0.003 \\
(0.066)\end{array}$ & $\begin{array}{l}-0.002 \\
(0.066)\end{array}$ & $\begin{array}{l}-0.003 \\
(0.064)\end{array}$ & $\begin{array}{l}-0.003 \\
(0.064)\end{array}$ \\
\hline Girl & $\begin{array}{l}0.124^{* * *} \\
(0.001)\end{array}$ & $\begin{array}{l}0.125^{* * *} \\
(0.001)\end{array}$ & $\begin{array}{l}0.125^{* * *} \\
(0.001)\end{array}$ & $\begin{array}{l}0.126^{* * *} \\
(0.001)\end{array}$ & $\begin{array}{l}0.126^{* * *} \\
(0.001)\end{array}$ & $\begin{array}{l}0.126^{* * *} \\
(0.001)\end{array}$ & $\begin{array}{l}0.128^{* * *} \\
(0.001)\end{array}$ & $\begin{array}{l}0.127^{* * *} \\
(0.001)\end{array}$ \\
\hline $\begin{array}{l}\text { Prob > F: }(\text { Lesbian parents } x \text { Boy })= \\
(\text { Lesbian parents } x \text { Girl })\end{array}$ & 0.768 & 0.968 & 0.971 & 0.956 & 0.958 & 0.971 & 0.946 & 0.952 \\
\hline $\begin{array}{l}\text { Prob }>\text { F: Lesbian parents } \times \text { Boy }= \\
0 \text { and Lesbian parents } x \text { Girl }=0\end{array}$ & 0.713 & 0.990 & 0.994 & 0.981 & 0.999 & 0.999 & 0.998 & 0.998 \\
\hline$N$ & & & & 419,602 & & & & \\
\hline Adjusted $R^{2}$ & 0.025 & 0.061 & 0.063 & 0.066 & 0.068 & 0.069 & 0.069 & 0.069 \\
\hline \multicolumn{9}{|c|}{ B. Comparison with children of married opposite-sex parents } \\
\hline Lesbian parents x Boy & $\begin{array}{c}0.045 \\
(0.083)\end{array}$ & $\begin{array}{l}-0.002 \\
(0.089)\end{array}$ & $\begin{array}{l}-0.001 \\
(0.088)\end{array}$ & $\begin{array}{c}0.005 \\
(0.089)\end{array}$ & $\begin{array}{l}-0.010 \\
(0.089)\end{array}$ & $\begin{array}{l}-0.012 \\
(0.089)\end{array}$ & $\begin{array}{l}-0.009 \\
(0.089)\end{array}$ & $\begin{array}{l}-0.010 \\
(0.089)\end{array}$ \\
\hline Lesbian parents x Girl & $\begin{array}{c}0.025 \\
(0.061)\end{array}$ & $\begin{array}{c}0.004 \\
(0.065)\end{array}$ & $\begin{array}{c}0.007 \\
(0.065)\end{array}$ & $\begin{array}{c}0.011 \\
(0.066)\end{array}$ & $\begin{array}{l}-0.004 \\
(0.066)\end{array}$ & $\begin{array}{l}-0.004 \\
(0.066)\end{array}$ & $\begin{array}{l}-0.005 \\
(0.065)\end{array}$ & $\begin{array}{l}-0.004 \\
(0.064)\end{array}$ \\
\hline Girl & $\begin{array}{c}0.113^{* * * *} \\
(0.002)\end{array}$ & $\begin{array}{c}0.114^{* * * *} \\
(0.002)\end{array}$ & $\begin{array}{l}0.114^{* * *} \\
(0.002)\end{array}$ & $\begin{array}{c}0.115^{* * *} \\
(0.002)\end{array}$ & $\begin{array}{c}0.115^{* * *} \\
(0.002)\end{array}$ & $\begin{array}{c}0.115^{* * *} \\
(0.002)\end{array}$ & $\begin{array}{c}0.117^{* * *} \\
(0.002)\end{array}$ & $\begin{array}{l}0.116^{* * *} \\
(0.002)\end{array}$ \\
\hline $\begin{array}{l}\text { Prob > F: (Lesbian parents } x \text { Boy })= \\
(\text { Lesbian parents } \times \text { Girl })\end{array}$ & 0.849 & 0.955 & 0.942 & 0.960 & 0.959 & 0.945 & 0.968 & 0.961 \\
\hline $\begin{array}{l}\text { Prob }>\text { F: Lesbian parents } x \text { Boy }= \\
0 \text { and Lesbian parents x Girl }=0\end{array}$ & 0.794 & 0.998 & 0.994 & 0.985 & 0.992 & 0.990 & 0.992 & 0.992 \\
\hline$N$ & & & & 189,960 & & & & \\
\hline Adjusted $R^{2}$ & 0.021 & 0.070 & 0.071 & 0.075 & 0.077 & 0.077 & 0.078 & 0.078 \\
\hline
\end{tabular}

Note: In column (1) control variables for the child's birth year are added. In column (2) control variables for the mother's education (7 levels), region of residence (county), and immigrant status are added. In column (3) control variables for the mother's age at the child's birth and an indicator for teenage mother are added. In column (4) controls for the child's birth quarter are added. In column (5) control variables for the number of older siblings and the number of younger siblings at age 10 are added. In column (6) a control variable for multiple births is added. In column (7) control variables for birth weight and having a low birth weight $(<2500 \mathrm{~g})$ are added. In column $(8)$ control

variables for hospitalization due to (all types and avoidable) diseases of the respiratory system are added. Robust standard errors, clustered at the biological mother, are shown in parentheses. ${ }^{*} p<0.10,{ }^{* *} p<0.05,{ }^{* * *} p<0.01$ 
Table 16. OLS estimates of average percentile rank in Math test scores at the national tests taken in 3rd grade.

\begin{tabular}{|c|c|c|c|c|c|c|c|c|}
\hline & $(1)$ & $(2)$ & (3) & (4) & (5) & (6) & (7) & $(8)$ \\
\hline \multicolumn{9}{|l|}{ A. Comparison with other children } \\
\hline Lesbian parents $\mathrm{x}$ Boy & $\begin{array}{l}8.8^{* *} \\
(3.5)\end{array}$ & $\begin{array}{c}5.2 \\
(3.4)\end{array}$ & $\begin{array}{c}5.1 \\
(3.4)\end{array}$ & $\begin{array}{c}5.5 \\
(3.4)\end{array}$ & $\begin{array}{c}5.3 \\
(3.4)\end{array}$ & $\begin{array}{c}5.2 \\
(3.4)\end{array}$ & $\begin{array}{c}5.5 \\
(3.4)\end{array}$ & $\begin{array}{c}5.5 \\
(3.4)\end{array}$ \\
\hline Lesbian parents x Girl & $\begin{array}{c}0.5 \\
(4.0)\end{array}$ & $\begin{array}{l}-1.2 \\
(4.2)\end{array}$ & $\begin{array}{l}-1.2 \\
(4.2)\end{array}$ & $\begin{array}{l}-0.9 \\
(4.3)\end{array}$ & $\begin{array}{l}-1.2 \\
(4.3)\end{array}$ & $\begin{array}{l}-1.2 \\
(4.3)\end{array}$ & $\begin{array}{l}-1.3 \\
(4.2)\end{array}$ & $\begin{array}{l}-1.2 \\
(4.2)\end{array}$ \\
\hline Girl & $\begin{array}{c}0.2^{* * *} \\
(0.1)\end{array}$ & $\begin{array}{l}0.3^{* * *} \\
(0.1)\end{array}$ & $\begin{array}{l}0.3^{* * *} \\
(0.1)\end{array}$ & $\begin{array}{l}0.3^{* * *} \\
(0.1)\end{array}$ & $\begin{array}{l}0.3^{* * *} \\
(0.1)\end{array}$ & $\begin{array}{l}0.3^{* * *} \\
(0.1)\end{array}$ & $\begin{array}{l}0.6^{* * *} \\
(0.1)\end{array}$ & $\begin{array}{l}0.5^{* * *} \\
(0.1)\end{array}$ \\
\hline $\begin{array}{l}\text { Prob > F: }(\text { Lesbian parents x Boy })= \\
(\text { Lesbian parents x Girl) }\end{array}$ & 0.114 & 0.235 & 0.246 & 0.238 & 0.235 & 0.242 & 0.212 & 0.216 \\
\hline $\begin{array}{l}\text { Prob }>\text { F: Lesbian parents } x \text { Boy }= \\
0 \text { and Lesbian parents x Girl }=0\end{array}$ & 0.039 & 0.298 & 0.309 & 0.254 & 0.280 & 0.294 & 0.253 & 0.259 \\
\hline$N$ & & & & 419,602 & & & & \\
\hline Adjusted $R^{2}$ & 0.000 & 0.073 & 0.076 & 0.083 & 0.086 & 0.087 & 0.090 & 0.090 \\
\hline \multicolumn{9}{|c|}{ B. Comparison with children of married opposite-sex parents } \\
\hline Lesbian parents $\mathrm{x}$ Boy & $\begin{array}{l}7.7^{* *} \\
(3.4)\end{array}$ & $\begin{array}{c}4.4 \\
(3.4)\end{array}$ & $\begin{array}{l}4.5 \\
(3.4)\end{array}$ & $\begin{array}{c}4.9 \\
(3.4)\end{array}$ & $\begin{array}{c}4.4 \\
(3.4)\end{array}$ & $\begin{array}{c}4.3 \\
(3.4)\end{array}$ & $\begin{array}{l}4.6 \\
(3.4)\end{array}$ & $\begin{array}{c}4.6 \\
(3.4)\end{array}$ \\
\hline Lesbian parents x Girl & $\begin{array}{l}-0.3 \\
(4.0)\end{array}$ & $\begin{array}{l}-1.7 \\
(4.2)\end{array}$ & $\begin{array}{l}-1.4 \\
(4.3)\end{array}$ & $\begin{array}{l}-1.2 \\
(4.3)\end{array}$ & $\begin{array}{l}-1.7 \\
(4.3)\end{array}$ & $\begin{array}{l}-1.7 \\
(4.3)\end{array}$ & $\begin{array}{l}-1.8 \\
(4.3)\end{array}$ & $\begin{array}{l}-1.8 \\
(4.3)\end{array}$ \\
\hline Girl & $\begin{array}{l}-0.1 \\
(0.1)\end{array}$ & $\begin{array}{l}-0.0 \\
(0.1)\end{array}$ & $\begin{array}{l}-0.0 \\
(0.1)\end{array}$ & $\begin{array}{c}0.0 \\
(0.1)\end{array}$ & $\begin{array}{c}0.0 \\
(0.1)\end{array}$ & $\begin{array}{l}0.0 \\
(0.1)\end{array}$ & $\begin{array}{l}0.3^{* * *} \\
(0.1)\end{array}$ & $\begin{array}{l}0.2^{* *} \\
(0.1)\end{array}$ \\
\hline $\begin{array}{l}\text { Prob > F: }(\text { Lesbian parents } x \text { Boy })= \\
(\text { Lesbian parents x Girl })\end{array}$ & 0.127 & 0.258 & 0.279 & 0.268 & 0.265 & 0.273 & 0.240 & 0.245 \\
\hline $\begin{array}{l}\text { Prob }>\text { F: Lesbian parents } x \text { Boy }= \\
0 \text { and Lesbian parents x Girl }=0\end{array}$ & 0.081 & 0.406 & 0.403 & 0.339 & 0.399 & 0.417 & 0.362 & 0.371 \\
\hline$N$ & & & & 189,960 & & & & \\
\hline Adjusted $R^{2}$ & 0.000 & 0.089 & 0.091 & 0.098 & 0.101 & 0.102 & 0.105 & 0.105 \\
\hline
\end{tabular}

Note: In column (1) control variables for the child's birth year are added. In column (2) control variables for the mother's education (7 levels), region of residence (county), and immigrant status are added. In column (3) control variables for the mother's age at the child's birth and an indicator for teenage mother are added. In column (4) controls for the child's birth quarter are added. In column (5) control variables for the number of older siblings and the number of younger siblings at age 10 are added. In column (6) a control variable for multiple births is added. In column (7) control variables for birth weight and having a low birth weight $(<2500 \mathrm{~g})$ are added. In column $(8)$ control

variables for hospitalization due to (all types and avoidable) diseases of the respiratory system are added. Robust standard errors, clustered at the biological mother, are shown

in parentheses. ${ }^{*} p<0.10,{ }^{* *} p<0.05,{ }^{* * *} p<0.01$ 
Table 17. OLS estimates of average percentile rank in Swedish test scores at the national tests taken in 3rd grade.

\begin{tabular}{|c|c|c|c|c|c|c|c|c|}
\hline & $(1)$ & $(2)$ & (3) & $(4)$ & $(5)$ & (6) & (7) & (8) \\
\hline \multicolumn{9}{|l|}{ A. Comparison with other children } \\
\hline Lesbian parents x Boy & $\begin{array}{c}10.9^{* * *} \\
(4.2)\end{array}$ & $\begin{array}{c}6.9 \\
(4.3)\end{array}$ & $\begin{array}{c}6.7 \\
(4.3)\end{array}$ & $\begin{array}{l}7.2^{*} \\
(4.3)\end{array}$ & $\begin{array}{c}6.5 \\
(4.3)\end{array}$ & $\begin{array}{c}6.4 \\
(4.3)\end{array}$ & $\begin{array}{c}6.5 \\
(4.3)\end{array}$ & $\begin{array}{c}6.5 \\
(4.3)\end{array}$ \\
\hline Lesbian parents x Girl & $\begin{array}{l}8.0^{* * *} \\
(3.2)\end{array}$ & $\begin{array}{l}6.1^{*} \\
(3.2)\end{array}$ & $\begin{array}{l}5.8^{*} \\
(3.2)\end{array}$ & $\begin{array}{l}6.1^{*} \\
(3.2)\end{array}$ & $\begin{array}{l}5.4^{*} \\
(3.3)\end{array}$ & $\begin{array}{l}5.4^{*} \\
(3.3)\end{array}$ & $\begin{array}{l}5.4^{*} \\
(3.2)\end{array}$ & $\begin{array}{l}5.4^{*} \\
(3.2)\end{array}$ \\
\hline Girl & $\begin{array}{l}5.8^{* * * *} \\
(0.1)\end{array}$ & $\begin{array}{l}5.8^{* * *} \\
(0.1)\end{array}$ & $\begin{array}{l}5.8^{* * *} \\
(0.1)\end{array}$ & $\begin{array}{l}5.9^{* * *} \\
(0.1)\end{array}$ & $\begin{array}{l}5.9^{* * *} \\
(0.1)\end{array}$ & $\begin{array}{l}5.9^{* * *} \\
(0.1)\end{array}$ & $\begin{array}{l}6.0^{* * *} \\
(0.1)\end{array}$ & $\begin{array}{l}6.0^{* * *} \\
(0.1)\end{array}$ \\
\hline $\begin{array}{l}\text { Prob > F: }(\text { Lesbian parents x Boy })= \\
(\text { Lesbian parents x Girl })\end{array}$ & 0.573 & 0.880 & 0.867 & 0.842 & 0.837 & 0.858 & 0.826 & 0.834 \\
\hline $\begin{array}{l}\text { Prob }>\text { F: Lesbian parents } \times \text { Boy }= \\
0 \text { and Lesbian parents } x \text { Girl }=0\end{array}$ & 0.001 & 0.046 & 0.059 & 0.042 & 0.081 & 0.083 & 0.078 & 0.077 \\
\hline$N$ & & & & & 419,602 & & & \\
\hline Adjusted $R^{2}$ & 0.015 & 0.083 & 0.086 & 0.093 & 0.099 & 0.099 & 0.100 & 0.100 \\
\hline \multicolumn{9}{|c|}{ B. Comparison with children of married opposite-sex parents } \\
\hline Lesbian parents x Boy & $\begin{array}{l}10.1^{* *} \\
(4.2)\end{array}$ & $\begin{array}{c}6.1 \\
(4.3)\end{array}$ & $\begin{array}{c}6.2 \\
(4.3)\end{array}$ & $\begin{array}{c}6.7 \\
(4.3)\end{array}$ & $\begin{array}{c}5.8 \\
(4.3)\end{array}$ & $\begin{array}{l}5.6 \\
(4.3)\end{array}$ & $\begin{array}{c}5.8 \\
(4.3)\end{array}$ & $\begin{array}{c}5.8 \\
(4.3)\end{array}$ \\
\hline Lesbian parents x Girl & $\begin{array}{l}7.5^{* *} \\
(3.2)\end{array}$ & $\begin{array}{l}5.7^{*} \\
(3.2)\end{array}$ & $\begin{array}{l}5.8^{*} \\
(3.2)\end{array}$ & $\begin{array}{l}6.1^{*} \\
(3.3)\end{array}$ & $\begin{array}{c}5.2 \\
(3.3)\end{array}$ & $\begin{array}{c}5.2 \\
(3.3)\end{array}$ & $\begin{array}{l}5.1 \\
(3.2)\end{array}$ & $\begin{array}{c}5.1 \\
(3.2)\end{array}$ \\
\hline Girl & $\begin{array}{l}5.4^{* * *} \\
(0.1)\end{array}$ & $\begin{array}{l}5.5^{* * *} \\
(0.1)\end{array}$ & $\begin{array}{l}5.5^{* * *} \\
(0.1)\end{array}$ & $\begin{array}{l}5.5^{* * *} \\
(0.1)\end{array}$ & $\begin{array}{l}5.5^{* * *} \\
(0.1)\end{array}$ & $\begin{array}{l}5.6^{* * *} \\
(0.1)\end{array}$ & $\begin{array}{l}5.7^{* * *} \\
(0.1)\end{array}$ & $\begin{array}{l}5.7^{* * *} \\
(0.1)\end{array}$ \\
\hline $\begin{array}{l}\text { Prob > F: }(\text { Lesbian parents x Boy })= \\
(\text { Lesbian parents x Girl) }\end{array}$ & 0.619 & 0.938 & 0.947 & 0.918 & 0.910 & 0.931 & 0.898 & 0.908 \\
\hline $\begin{array}{l}\text { Prob }>\text { F: Lesbian parents } x \text { Boy }= \\
0 \text { and Lesbian parents x Girl }=0\end{array}$ & 0.003 & 0.076 & 0.072 & 0.051 & 0.119 & 0.123 & 0.115 & 0.115 \\
\hline$N$ & & & & 189,960 & & & & \\
\hline Adjusted $R^{2}$ & 0.013 & 0.105 & 0.108 & 0.115 & 0.120 & 0.121 & 0.121 & 0.122 \\
\hline
\end{tabular}

Note: In column (1) control variables for the child's birth year are added. In column (2) control variables for the mother's education (7 levels), region of residence (county), and immigrant status are added. In column (3) control variables for the mother's age at the child's birth and an indicator for teenage mother are added. In column (4) controls for the child's birth quarter are added. In column (5) control variables for the number of older siblings and the number of younger siblings at age 10 are added. In column (6) a control variable for multiple births is added. In column (7) control variables for birth weight and having a low birth weight $(<2500 \mathrm{~g})$ are added. In column $(8)$ control

variables for hospitalization due to (all types and avoidable) diseases of the respiratory system are added. Robust standard errors, clustered at the biological mother, are shown

in parentheses. ${ }^{*} p<0.10,{ }^{* *} p<0.05,{ }^{* * *} p<0.01$ 
Table 18. Estimates by definition of lesbian parenthood according to time of marriage (or partnership) since birth of the child.

\begin{tabular}{|c|c|c|c|c|c|c|c|c|c|c|c|c|c|}
\hline \multirow[b]{2}{*}{ Outcome } & & \multicolumn{2}{|c|}{ At birth } & \multicolumn{2}{|c|}{ Within 6 months } & \multicolumn{2}{|c|}{ Within 12 months } & \multicolumn{2}{|c|}{ Within 36 months } & \multicolumn{2}{|c|}{ Within 60 months } & \multicolumn{2}{|c|}{ Any time } \\
\hline & & (1) & (2) & (1) & (2) & (1) & (2) & (1) & (2) & (1) & (1) & (1) & (2) \\
\hline $\begin{array}{l}\text { Log } \\
\text { birth weight }\end{array}$ & $\begin{array}{l}\text { Lesb par } \\
\text { x Boy } \\
\text { Lesb par } \\
\text { x Girl }\end{array}$ & $\begin{array}{c}-0.023^{*} \\
(0.013) \\
-0.029^{* *} \\
(0.012)\end{array}$ & $\begin{array}{c}-0.028^{* *} \\
(0.013) \\
-0.036^{* * *} \\
(0.012)\end{array}$ & $\begin{array}{c}-0.023^{*} \\
(0.012) \\
-0.025^{* *} \\
(0.011)\end{array}$ & $\begin{array}{c}-0.029^{* *} \\
(0.012) \\
-0.032^{* * *} \\
(0.011)\end{array}$ & $\begin{array}{l}-0.021^{*} \\
(0.012) \\
-0.023^{* *} \\
(0.010)\end{array}$ & $\begin{array}{c}-0.027^{* *} \\
(0.012) \\
-0.030^{* * *} \\
(0.011)\end{array}$ & $\begin{array}{c}-0.013 \\
(0.011) \\
-0.022^{* *} \\
(0.010)\end{array}$ & $\begin{array}{c}-0.019^{*} \\
(0.011) \\
-0.028^{* * *} \\
(0.010)\end{array}$ & $\begin{array}{c}-0.011 \\
(0.010) \\
-0.020^{* *} \\
(0.010)\end{array}$ & $\begin{array}{c}-0.016 \\
(0.010) \\
-0.026^{* * *} \\
(0.010)\end{array}$ & $\begin{array}{c}-0.006 \\
(0.008) \\
-0.015^{* *} \\
(0.008)\end{array}$ & $\begin{array}{c}-0.010 \\
(0.008) \\
-0.020^{* *} \\
(0.008)\end{array}$ \\
\hline $\begin{array}{l}\text { Low } \\
\text { birth weight }\end{array}$ & $\begin{array}{l}\text { Lesb par } \\
\text { x Boy } \\
\text { Lesb par } \\
\text { x Girl }\end{array}$ & $\begin{array}{l}0.005 \\
(0.014) \\
0.034^{* *} \\
(0.016)\end{array}$ & $\begin{array}{l}0.007 \\
(0.014) \\
0.037^{* *} \\
(0.016)\end{array}$ & $\begin{array}{l}0.007 \\
(0.013) \\
0.029^{* *} \\
(0.014)\end{array}$ & $\begin{array}{l}0.009 \\
(0.013) \\
0.031^{* *} \\
(0.014)\end{array}$ & $\begin{array}{c}0.005 \\
(0.013) \\
0.025^{*} \\
(0.014)\end{array}$ & $\begin{array}{l}0.008 \\
(0.013) \\
0.028^{* *} \\
(0.014)\end{array}$ & $\begin{array}{l}-0.001 \\
(0.011) \\
0.030^{* *} \\
(0.013)\end{array}$ & $\begin{array}{l}0.002 \\
(0.011) \\
0.032^{* *} \\
(0.013)\end{array}$ & $\begin{array}{l}-0.002 \\
(0.010) \\
0.032^{* *} \\
(0.013)\end{array}$ & $\begin{array}{l}0.000 \\
(0.010) \\
0.034^{* *} \\
(0.013)\end{array}$ & $\begin{array}{l}-0.003 \\
(0.007) \\
0.031^{* * *} \\
(0.010)\end{array}$ & $\begin{array}{l}-0.001 \\
(0.007) \\
0.032^{* * *} \\
(0.010)\end{array}$ \\
\hline $\begin{array}{l}\text { Hosp due to resp } \\
\text { system }\end{array}$ & $\begin{array}{l}\text { Lesb par } \\
\text { x Boy } \\
\text { Lesb par } \\
\text { x Girl }\end{array}$ & $\begin{array}{c}-0.037^{* * *} \\
(0.013) \\
0.031^{*} \\
(0.016)\end{array}$ & $\begin{array}{l}-0.029^{* *} \\
(0.013) \\
0.037^{* *} \\
(0.016)\end{array}$ & $\begin{array}{c}-0.034^{* * *} \\
(0.013) \\
0.024 \\
(0.015)\end{array}$ & $\begin{array}{c}-0.025^{*} \\
(0.013) \\
0.030^{*} \\
(0.015)\end{array}$ & $\begin{array}{c}-0.033^{* * *} \\
(0.013) \\
0.022 \\
(0.015)\end{array}$ & $\begin{array}{c}-0.025^{*} \\
(0.013) \\
0.027^{*} \\
(0.015)\end{array}$ & $\begin{array}{c}-0.036^{* * *} \\
(0.012) \\
0.019 \\
(0.014)\end{array}$ & $\begin{array}{c}-0.028^{* *} \\
(0.012) \\
0.024^{*} \\
(0.014)\end{array}$ & $\begin{array}{c}-0.033^{* * *} \\
(0.012) \\
0.019 \\
(0.013)\end{array}$ & $\begin{array}{c}-0.026^{* *} \\
(0.012) \\
0.023^{*} \\
(0.013)\end{array}$ & $\begin{array}{c}-0.002 \\
(0.011) \\
0.035^{* * *} \\
(0.011)\end{array}$ & $\begin{array}{c}0.002 \\
(0.011) \\
0.038^{* * *} \\
(0.011)\end{array}$ \\
\hline \multirow{2}{*}{$\begin{array}{l}\text { Hosp due to } \\
\text { avoidable dis } \\
\text { resp system }\end{array}$} & $\begin{array}{l}\text { Lesb par } \\
\mathrm{x} \text { Boy }\end{array}$ & $\begin{array}{l}-0.012 \\
(0.009)\end{array}$ & $\begin{array}{l}-0.009 \\
(0.009)\end{array}$ & $\begin{array}{l}-0.006 \\
(0.010)\end{array}$ & $\begin{array}{l}-0.002 \\
(0.010)\end{array}$ & $\begin{array}{l}-0.007 \\
(0.009)\end{array}$ & $\begin{array}{l}-0.004 \\
(0.009)\end{array}$ & $\begin{array}{l}-0.009 \\
(0.008)\end{array}$ & $\begin{array}{l}-0.006 \\
(0.008)\end{array}$ & $\begin{array}{l}-0.012 \\
(0.008)\end{array}$ & $\begin{array}{l}-0.009 \\
(0.008)\end{array}$ & $\begin{array}{c}0.005 \\
(0.007)\end{array}$ & $\begin{array}{c}0.007 \\
(0.007)\end{array}$ \\
\hline & $\begin{array}{l}\text { Lesb par } \\
\text { x Girl }\end{array}$ & $\begin{array}{c}0.009 \\
(0.010)\end{array}$ & $\begin{array}{c}0.011 \\
(0.010)\end{array}$ & $\begin{array}{c}0.006 \\
(0.009)\end{array}$ & $\begin{array}{c}0.009 \\
(0.009)\end{array}$ & $\begin{array}{c}0.007 \\
(0.009)\end{array}$ & $\begin{array}{c}0.009 \\
(0.009)\end{array}$ & $\begin{array}{c}0.003 \\
(0.008)\end{array}$ & $\begin{array}{c}0.006 \\
(0.008)\end{array}$ & $\begin{array}{c}0.005 \\
(0.008)\end{array}$ & $\begin{array}{c}0.007 \\
(0.008)\end{array}$ & $\begin{array}{c}0.012^{*} \\
(0.007)\end{array}$ & $\begin{array}{l}0.013^{* *} \\
(0.007)\end{array}$ \\
\hline $\mathrm{N}$ (lesbian + othe & oarents) & \multicolumn{2}{|c|}{$692+1,539,068$} & \multicolumn{2}{|c|}{$750+1,539,010$} & \multicolumn{2}{|c|}{$780+1,538,980$} & \multicolumn{2}{|c|}{$881+1,538,879$} & \multicolumn{2}{|c|}{$961+1,538,760$} & \multicolumn{2}{|c|}{$1,678+1,538,082$} \\
\hline
\end{tabular}

Note: In column (1) controls for the child's birth year are added. In column (2) control variables for the mother's education (7 levels), region of residence (county), immigrant status, and an indicator for whether the birth mother has moved between counties during the period of observation (only in health analysis) are added. Robust standard errors, clustered at the biological mother, are shown in parentheses. ${ }^{*} p<0.10,{ }^{* *} p<0.05,{ }^{* * *} p<0.01$ 
Table 19. Estimates by definition of lesbian parenthood according to time of marriage (or partnership) since birth of the child.

\begin{tabular}{|c|c|c|c|c|c|c|c|c|c|c|c|c|c|}
\hline \multirow[b]{2}{*}{ Outcome } & & \multicolumn{2}{|c|}{ At birth } & \multicolumn{2}{|c|}{ Within 6 months } & \multicolumn{2}{|c|}{ Within 12 months } & \multicolumn{2}{|c|}{ Within 36 months } & \multicolumn{2}{|c|}{ Within 60 months } & \multicolumn{2}{|c|}{ Any time } \\
\hline & & (1) & (2) & (1) & (2) & (1) & $(2)$ & (1) & (2) & (1) & (1) & (1) & (2) \\
\hline \multirow[t]{4}{*}{ Pass Math } & Lesb par $\mathrm{x}$ & $0.130^{*}$ & 0.077 & $0.130^{*}$ & 0.077 & 0.080 & 0.036 & 0.080 & 0.038 & 0.080 & 0.049 & 0.004 & -0.004 \\
\hline & Boy & $(0.070)$ & $(0.075)$ & $(0.070)$ & $(0.075)$ & $(0.073)$ & $(0.077)$ & $(0.066)$ & $(0.069)$ & $(0.059)$ & $(0.062)$ & $(0.035)$ & $(0.035)$ \\
\hline & Lesb par $\mathrm{x}$ & -0.019 & -0.046 & -0.010 & -0.036 & 0.001 & -0.022 & 0.009 & -0.006 & 0.038 & 0.037 & -0.041 & -0.032 \\
\hline & Girl & $(0.088)$ & $(0.091)$ & $(0.082)$ & $(0.084)$ & $(0.080)$ & $(0.083)$ & $(0.074)$ & $(0.076)$ & $(0.065)$ & $(0.070)$ & $(0.037)$ & $(0.037)$ \\
\hline \multirow[t]{4}{*}{ Pass Swedish } & Lesb par $\mathrm{x}$ & 0.058 & 0.010 & 0.058 & 0.010 & 0.057 & 0.016 & 0.070 & 0.032 & 0.052 & 0.024 & -0.020 & -0.027 \\
\hline & Boy & $(0.083)$ & $(0.089)$ & $(0.083)$ & $(0.089)$ & $(0.078)$ & $(0.082)$ & $(0.069)$ & $(0.073)$ & $(0.063)$ & $(0.065)$ & $(0.037)$ & $(0.037)$ \\
\hline & Lesb par $\mathrm{x}$ & 0.008 & -0.016 & 0.027 & 0.005 & 0.032 & 0.012 & 0.049 & 0.037 & 0.070 & 0.070 & 0.029 & 0.039 \\
\hline & Girl & $(0.070)$ & $(0.073)$ & $(0.061)$ & $(0.064)$ & $(0.059)$ & $(0.063)$ & $(0.052)$ & $(0.055)$ & $(0.043)$ & $(0.047)$ & $(0.027)$ & $(0.028)$ \\
\hline \multirow{4}{*}{$\begin{array}{l}\text { Perc rank } \\
\text { Math }\end{array}$} & Lesb par $\mathrm{x}$ & $8.8^{* *}$ & 5.2 & $8.8^{* *}$ & 5.2 & $8.4^{* * *}$ & $5.4^{*}$ & $6.5^{* *}$ & 3.7 & 4.0 & 2.0 & 1.7 & 1.2 \\
\hline & Boy & (3.5) & (3.4) & (3.5) & (3.4) & $(3.2)$ & $(3.2)$ & $(2.9)$ & $(2.9)$ & $(2.7)$ & $(2.7)$ & (1.5) & $(1.5)$ \\
\hline & Lesb par $\mathrm{x}$ & 0.0 & -1.8 & 0.5 & -1.2 & 0.7 & -0.8 & 0.0 & -1.0 & 1.0 & 0.9 & 0.0 & 0.7 \\
\hline & Girl & $(4.3)$ & $(4.5)$ & $(4.0)$ & $(4.2)$ & $(3.9)$ & $(4.1)$ & (3.6) & (3.7) & (3.1) & (3.3) & (1.7) & $(1.7)$ \\
\hline \multirow{3}{*}{$\begin{array}{l}\text { Perc rank } \\
\text { Swedish }\end{array}$} & Lesb par $\mathrm{x}$ & $10.9^{* * *}$ & 6.9 & $10.9^{* * *}$ & 6.9 & $11.8^{* * *}$ & $8.4^{* *}$ & $8.1^{* *}$ & 4.9 & $6.3^{*}$ & 4.0 & 2.8 & 2.2 \\
\hline & Boy & $(4.2)$ & (4.3) & (4.2) & (4.3) & $(3.7)$ & (3.9) & $(3.7)$ & $(3.7)$ & $(3.6)$ & $(3.5)$ & (1.9) & $(1.8)$ \\
\hline & Lesb par $\mathrm{x}$ & $6.2^{*}$ & 4.1 & $8.0^{* *}$ & $6.1^{*}$ & $7.3^{* *}$ & $5.6^{*}$ & $6.6^{* * *}$ & $5.5^{*}$ & $5.2^{*}$ & $5.1^{* *}$ & 2.8 & $3.4^{* * *}$ \\
\hline \multicolumn{2}{|c|}{$\mathrm{N}$ (lesbian + other parents) } & \multicolumn{2}{|c|}{$52+419,550$} & \multicolumn{2}{|c|}{$56+419,546$} & \multicolumn{2}{|c|}{$61+419,541$} & \multicolumn{2}{|c|}{$72+419,530$} & \multicolumn{2}{|c|}{$90+419,512$} & \multicolumn{2}{|c|}{$323+419,279$} \\
\hline
\end{tabular}

Note: In column (1) controls for the child's birth year are added. In column (2) control variables for the mother's education (7 levels), region of residence (county), and immigrant status are added. Robust standard errors, clustered at the biological mother, are shown in parentheses. ${ }^{*} p<0.10{ }^{* *} p<0.05,{ }^{* * *} p<0.01$. 